Article

\title{
New Inverse Emulsion-Polymerized Iron/Polyaniline Composites for Permanent, Highly Magnetic Iron Compounds via Calcination
}

\author{
Tar-Hwa Hsieh ${ }^{1}$, Lin-Chia Ho ${ }^{2}$, Yen-Zen Wang ${ }^{3, *}{ }^{\dagger}$, Ko-Shan Ho ${ }^{1, *,+}$, Cheng-Hsien Tsai ${ }^{1}$ (D) and Li-Fan Hung ${ }^{1}$ \\ 1 Department of Chemical and Materials Engineering, National Kaohsiung University of Science \& Technology, \\ 415 Chien-Kuo Rd., Kaohsiung 80782, Taiwan; thh@nkust.edu.tw (T.-H.H.); chtsai@nkust.edu.tw (C.-H.T.); \\ fish09331028@gmail.com (L.-F.H.) \\ 2 Tri-Service General Hospital, 325 Sec. 2 Chenggong Rd., Neihu District, Taipei City 11490, Taiwan; \\ 404010073@mail.ndmctsgh.edu.tw \\ 3 Department of Chemical and Materials Engineering, National Yu-Lin University of Science \& Technology, 123, \\ Sec. 3, University Rd., Dou-Liu City, Yun-Lin 64301, Taiwan \\ * Correspondence: wangzen@yuntech.edu.tw (Y.-Z.W.); hks@nkust.edu.tw (K.-S.H.) \\ + These authors equally contributed to this work.
}

\section{check for} updates

Citation: Hsieh, T.-H.; Ho, L.-C.; Wang, Y.-Z.; Ho, K.-S.; Tsai, C.-H.; Hung, L.-F. New Inverse Emulsion-Polymerized Iron/Polyaniline Composites for Permanent, Highly Magnetic Iron Compounds via Calcination. Polymers 2021, 13, 3240. https://doi.org/ $10.3390 /$ polym 13193240

Academic Editor:

Mohanapriya Venkataraman

Received: 30 August 2021

Accepted: 22 September 2021

Published: 24 September 2021

Publisher's Note: MDPI stays neutral with regard to jurisdictional claims in published maps and institutional affiliations.

Copyright: (C) 2021 by the authors. Licensee MDPI, Basel, Switzerland. This article is an open access article distributed under the terms and conditions of the Creative Commons Attribution (CC BY) license (https:// creativecommons.org/licenses/by/ $4.0 /)$.

\begin{abstract}
The hydrophilic initiator potassium persulfate (KPS) was converted into a hydrophobic molecule by complexing with cetyltrimethylammonium bromide (CTAB) at both ends of the molecule (CTAPSu). Inverse emulsion polymerization thus proceeded inside micelles dispersed in the affluent toluene with CTAPSu as the initiator. Polyaniline (PANI) formed inside the micelles and entangled with $\mathrm{Fe}_{3} \mathrm{O}_{4}$ nanoparticles already esterified with oleic acid (OA). Iron composites consisted of OAesterified $\mathrm{Fe}_{3} \mathrm{O}_{4}$ nanoparticles covered with PANI after de-emulsification. After calcination at $950{ }^{\circ} \mathrm{C}$ in an argon atmosphere, the resultant iron compound was a mixture of $\alpha$-Fe (ferrite) and $\mathrm{Fe}_{3} \mathrm{C}$ (cementite), as determined by X-ray diffraction. Eventually, the calcined iron compounds (mixtures) demonstrated superparamagnetic properties with a high saturation magnetization (Ms) of $197 \mathrm{emu} / \mathrm{g}$, which decayed to $160 \mathrm{emu} / \mathrm{g}$ after exposure to the atmosphere for four months.
\end{abstract}

Keywords: inverse emulsion polymerization; polyaniline; superparamagnetic

\section{Introduction}

High-magnetic-moment materials are basic components of devices used in electronic, optical, and environmental fields. Moreover, they are used in the cell fabrication field as catalysts or electrodes since they can store power or hydrogen. More applications in medical areas include drug release and targeting, biosensors, imaging construction, and diagnosis of specific diseases.

Some of these applications need devices or instruments made of materials owning superparamagnetic properties and a high magnetic moment. The most common paramagnetic material is magnetite, usually obtained with the sol-gel method [1] at low temperature without calcination. However, its saturation magnetization (Ms) is below $100 \mathrm{emu} \mathrm{g}^{-1}$, i.e., whose magnetic moment is not high enough to meet the requirements of the applications. We have been working on preparing materials with Ms above $100 \mathrm{emu} \mathrm{g}^{-1}$ and focused on materials such as cementite $\left(\mathrm{Fe}_{3} \mathrm{C}\right)$ [2], ferric nitride $\left(\alpha^{\prime \prime}-\mathrm{Fe}_{\mathrm{x}} \mathrm{N}_{\mathrm{y}}\right)$ [3-5], and ferrite $(\alpha-\mathrm{Fe})[6]$, all of which have an Ms above $150 \mathrm{emu} \mathrm{g}^{-1}$.

Among high-magnetic-moment materials, ferrite is one of the best iron-related materials. However, ferrite is very unstable and can be oxidized to ferric oxide in few days in air. Using a convenient precursor (nano- $\mathrm{Fe}_{3} \mathrm{O}_{4}$ ), we are able to fabricate other iron-containing composites owning magnetic moment and capability of anti-oxidation via calcination at high temperature $\left(>912^{\circ} \mathrm{C}\right)$ in an inert gas, which induced rearrangement of $\mathrm{Fe}, \mathrm{C}$, and $\mathrm{N}$ atoms. 
PANI(EB) (emeraldine form of polyaniline) is one of suitable long-chain polymers used to cover magnetic particles and able to provide both carbon and nitride sources for calcined compounds. There are also some other interesting applications concerning about calcined polyaniline-coated magnetic composites, such as EMI, microelectronics, medical treatments [7-10], etc. The eventual goal of different studies is to prepare a composite with a dominant ferrite core covered with hard/stable cementite or ferric nitride as the protecting material preventing further oxidation in the atmosphere.

PANI(EB) is usually prepared with the common emulsion polymerization [11-15] method in the affluent water, where aniline monomers (anilinium) are soluble. However, nano- $\mathrm{Fe}_{3} \mathrm{O}_{4}$ obtained from the sol-gel approach carries hydroxyl groups on the surface and can disperse well in water as well. The hydroxyl groups of nano- $\mathrm{Fe}_{3} \mathrm{O}_{4}$ can firmly associate with anilinium monomers in water before polymerization. Eventually, the resultant PANI (polyaniline) molecules are fully covered with $\mathrm{Fe}_{3} \mathrm{O}_{4}$ nanoparticles. Furthermore, $\mathrm{Fe}_{3} \mathrm{O}_{4}$ nanoparticles would remain on the surface of the nanofibrous PANI molecules [16-23]. The high-magnetic-moment nanoparticles obtained after high-temperature calcination remain on PANI surface rather than covered by PANI can easily oxidize in the atmosphere, which results in the loss of the magnetic moment. To introduce precursor $\mathrm{Fe}_{3} \mathrm{O}_{4}$ nanoparticles in PANI before calcination, an inverse emulsion system was designed, so to constraint both nano- $\mathrm{Fe}_{3} \mathrm{O}_{4}$ and anilinium monomers in surfactant-stabilized micelles of water in affluent toluene. To minimize the number of initiator molecules into the micelles in order to increase the molecular weight (MW) of the resultant PANIs, water soluble KPS (potassium persulfate) initiators are both end-capped with CTAB (cetylammonium bromide), converting it into more hydrophobic CTAPSu (cetylammonium persulfate). In fact, without this transformation, most of the hydrophilic initiators (KPS) would enter into the water micelles, and the system would be similar to that for inverse-suspension polymerization, leading to polymers with a lower MW and reducing the area of PANIs, which can are able to cover by the magnetic particles. Therefore, most of theCTAPSu are soluble in the toluene phase due to the long aliphatic wings on both ends of the molecule and only few molecules will diffuse into the water-containing micelles in which $\mathrm{Fe}_{3} \mathrm{O}_{4}$ and anilinium monomers are present. Consequently, the polymerization can proceed with only a limited amount of initiators in the micelles to ignite the polymerization, and high-MW PANIs can be obtained, which can firmly cover $\mathrm{Fe}_{3} \mathrm{O}_{4}$ nanoparticles inside and well-protect the formed iron composites from oxidation after calcination. A nano- $\mathrm{Fe}_{3} \mathrm{O}_{4} / \mathrm{PANI}$ composite via regular emulsion polymerization was also prepared for comparison.

The N- and C-doped iron composite before and after calcination at $950{ }^{\circ} \mathrm{C}$ in an argon atmosphere were characterized by FTIR (Fourier transform infrared spectroscopy) and X-ray diffraction (XRD) to analyze the composition of the obtained iron compounds (cementite, ferrite, or ferric nitride). We studied the morphologies of $\mathrm{N}$ - and C-doped iron-composites before and after calcination by SEM (scanning electron microscopy) and TEM (transmission electron microscopy).

\section{Materials and Methods}

\subsection{Preparation}

\subsubsection{Preparation of $\mathrm{Nano}-\mathrm{Fe}_{3} \mathrm{O}_{4}$}

We mixed 0.02 moles $(4.33 \mathrm{~g})$ of ferric chloride hexahydrate $\left(\mathrm{FeCl}_{3} \cdot 6 \mathrm{H}_{2} \mathrm{O}\right.$, J.T. Baker, Phillipsburg, NJ, USA) and 0.01 mole $(1.99 \mathrm{~g})$ of ferrous chloride tetrahydrate $\left(\mathrm{FeCl}_{2} \cdot 4 \mathrm{H}_{2} \mathrm{O}\right.$, J.T. Baker, Phillipsburg, NJ, USA) with $40 \mathrm{~mL}$ of deionized water in a beaker stirred with a magnetic stirrer. The resultant solution was transferred to a round-bottom three-necked flask that was equipped with a water condenser in one of the mouths. One of the remaining two mouths was purged with high-purity nitrogen to reduce the oxygen content above the atmosphere of the reaction mixture, the other one was the gas release outlet. The reaction solution was heated to $80^{\circ} \mathrm{C}$ in a silicone oil bath for $10 \mathrm{~min}$, with continuous supply of nitrogen. Then, some ammonia was introduced to adjust the alkalinity of the solution and start the reaction. The reaction continued for 30 min under magnetic stirring. 
Then, a powerful magnet was placed on the bottom of the reactor to attract the precipitate. The precipitate was washed several times with deionized water, and the clear solution in the upper layer was discarded. The isolated black precipitate was ultrasonicated in an oscillator for $20 \mathrm{~min}$ then dried in an oven for $12 \mathrm{~h}$ at $50{ }^{\circ} \mathrm{C}$; eventually, nano- $\mathrm{Fe}_{3} \mathrm{O}_{4}$ was obtained [1,24].

\subsubsection{Preparation of Nano-Oleated Nano- $\mathrm{Fe}_{3} \mathrm{O}_{4}\left(\mathrm{Fe}_{3} \mathrm{O}_{4}(\mathrm{OA})\right)$}

$\mathrm{Fe}_{3} \mathrm{O}_{4}(\mathrm{OA})$ particles were prepared with the procedure previously described [1,24], except that $10 \mathrm{~mL}$ ( 0.03 mole) of OA was introduced before the addition of ammonium water, which was used to obtain an alkaline reaction mixture.

\subsubsection{Converting CTAB to CTAPSu}

The hydrophobic persulfate initiators for inverse emulsion polymerization were prepared by dissolving CTAB in water through stirring for $40 \mathrm{~min}$ before introducing a double amount of KPS to the water mixture, which was stirred for additional $40 \mathrm{~min}$ and then poured into a large amount of toluene. The precipitated $\mathrm{KBr}$ was removed by filtration, and the toluene solvent was evaporated in a vacuum hood. Eventually, a CTAPSu cake carrying two long alkyl wings was obtained (Scheme 1). The obtained CTAPSu cake was dried in a vacuum oven overnight.
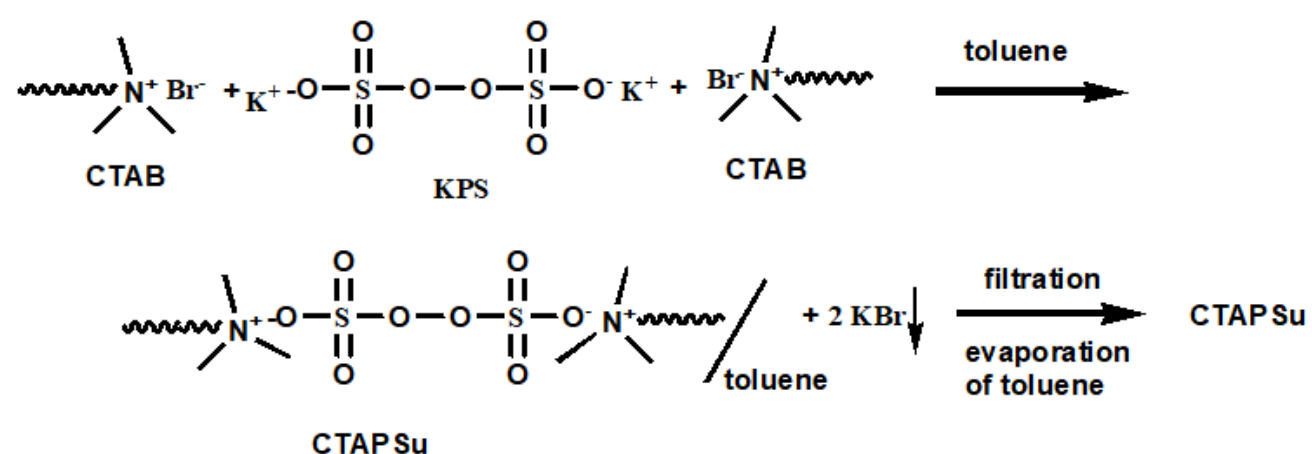

Scheme 1. Preparation of CTAPSu.

\subsubsection{Preparation of $\mathrm{PANI} / \mathrm{Fe}_{3} \mathrm{O}_{4}$ and $\mathrm{PANI} / \mathrm{Fe}_{3} \mathrm{O}_{4}(\mathrm{OA})$ )}

We dissolved $3 \mathrm{~g}$ (0.091 mol) n-dodecylbenzenesulfonic acid (HDBSA: Tokyo Kasei Kogyo Co., Tokyo, Japan) in $50 \mathrm{~mL}$ of de-ionized water. The mixture was slowly stirred until a homogeneous solution was obtained, followed by the addition of $9 \mathrm{~g}(0.0968 \mathrm{~mol})$ of aniline (Tokyo Kasei Kogyo Co., Tokyo, Japan); the solution was stirred until clear. Eventually, $\mathrm{Fe}_{3} \mathrm{O}_{4}$ or $\mathrm{Fe}_{3} \mathrm{O}_{4}(\mathrm{OA})$ obtained from the previous experiment $[1,24]$ was added, and the mixture was stirred again until homogeneous so to obtain a water phase. The concentration of DBSA was about $1.82 \mathrm{M}$, well above the critical concentration (CMC) to create micelles.

We dissolved $2 \mathrm{~g}$ of CTAB and 19.4 $\mathrm{g}$ of CTAPSu prepared in Section 2.1 .3 in $500 \mathrm{~mL}$ of toluene and poured only $5 \mathrm{~mL}$ of the water phase into the affluent toluene, with a volume ratio of 1:100. The inverse emulsified system was then created with anilinium monomers and $\mathrm{Fe}_{3} \mathrm{O}_{4}$ (or $\mathrm{Fe}_{3} \mathrm{O}_{4}(\mathrm{OA})$ ), which remained inside the micelles (inversely emulsified). After stirring, a W/O creamed solution formed, and the system was slightly heated to $40{ }^{\circ} \mathrm{C}$ and maintained for $3.5 \mathrm{~h}$. The inverse emulsion polymerization of PANI was stopped by pouring $200 \mathrm{~mL}$ of acetone (de-emulsifier), and the composites (PANI(ES) $/ \mathrm{Fe}_{3} \mathrm{O}_{4}$ or PANI(ES) $/ \mathrm{Fe}_{3} \mathrm{O}_{4}(\mathrm{OA})$ ) were precipitated, isolated by filtration, and dried in an oven overnight.

The composites were then de-doped in the affluent $1 \mathrm{M}$ ammonium water by stirring for 2 to 3 days to remove the doping protonic acid and sulfide compounds derived from the dissociation of persulfate initiators. A de-doped composite cake (PANI(EB) $/ \mathrm{Fe}_{3} \mathrm{O}_{4}$ or $\mathrm{PANI}(\mathrm{EB}) / \mathrm{Fe}_{3} \mathrm{O}_{4}(\mathrm{OA})$ ) was obtained from filtration and dried in an oven at $80{ }^{\circ} \mathrm{C}$ for one 
day. The $w t \%$ of $\mathrm{Fe}_{3} \mathrm{O}_{4}$ in the composite was about $40 \%$ according to the residue weight after $500{ }^{\circ} \mathrm{C}$ in the TGA thermogram in the presence of purging air.

A common emulsion polymerization experiment [25-27] was carried out with KPS as the initiator instead of CTAPSu with or without $\mathrm{Fe}_{3} \mathrm{O}_{4}$. Besides, HDBSA, which behaves as both surfactant and protonic acid in an inverse emulsion polymerization, was replaced by $\mathrm{CTAB}$ and $\mathrm{HCl}(\mathrm{aq})$. The obtained neat PANI and composite were called PANI(Em) (polyaniline prepared via regular emulsion polymerization) and $\mathrm{PANI}(\mathrm{Em}) / \mathrm{Fe}_{3} \mathrm{O}_{4}$, respectively. PANI prepared in such had a nanofibrous morphology [28,29].

\subsubsection{Calcination of the PANI/Iron Composites}

$\mathrm{PANI}(\mathrm{EB}) / \mathrm{Fe}_{3} \mathrm{O}_{4}$ or $\mathrm{PANI}(\mathrm{EB}) / \mathrm{Fe}_{3} \mathrm{O}_{4}(\mathrm{OA})$ prepared in Section 2.1.4 was calcined in a tube furnace ramping up to $950{ }^{\circ} \mathrm{C}$ at $10{ }^{\circ} \mathrm{C} \mathrm{min}-1$ and holding the temperature at $950{ }^{\circ} \mathrm{C}$ for $30 \mathrm{~min}$ in an argon atmosphere. The obtained $\mathrm{N}-, \mathrm{C}$-doped iron composites were called $\mathrm{FeNC}$ and $\mathrm{FeNC}(\mathrm{OA})$, depending on whether the precursor was $\mathrm{Fe}_{3} \mathrm{O}_{4}$ or $\mathrm{Fe}_{3} \mathrm{O}_{4}(\mathrm{OA})$, respectively. FeNC was kept at room temperature for two months and then renamed FeNC-2. FeNC(OA) was named $\mathrm{FeNC}(\mathrm{OA})-2$ or FeNC(OA)-4, respectively, after storage for two and four months at room temperature, respectively.

\subsection{Characterization}

\subsubsection{FTIR}

The main functional groups of neat $\mathrm{Fe}_{3} \mathrm{O}_{4}$ and various iron-compounds were assigned according to the FTIR spectra that were recorded on an IFS3000 v/s FTIR spectrometer (Bruker, Ettlingen, Germany) at room temperature with a resolution of $4 \mathrm{~cm}^{-1}$ and 16 scanning steps.

\subsubsection{Ultraviolet-Visible-Near-IR Spectroscopy (UV-Vis-NIR)}

The UV-Vis-NIR spectra of the samples were obtained with a Hitachi U-2001 and a DTS-1700 NIR Spectrometer (Nicosia, Cyprus). The wavelength used ranged from 300 to $1600 \mathrm{~nm}$.

\subsubsection{TGA (Thermogravimetric Analysis)}

The mass loss percentages of $\mathrm{PANI}(\mathrm{EB}) / \mathrm{Fe}_{3} \mathrm{O}_{4}(\mathrm{OA})$ upon calcination (thermal degradation) was monitored and recorded using TGA (TA SDT-2960, New Castle, DE, USA).

\subsubsection{SEM}

The size and morphology of various iron compounds were characterized by SEM (fieldemission gun-scanning electron microscope, AURIGAFE, Zeiss, Oberkochen, Germany). The samples were prepared from strewn on carbonic tape and followed by posting on ferric stage. The samples were also surface-plated with gold in a CVD process to improve the surface conductivity and obtain a higher resolution.

\subsubsection{TEM}

Photos of the samples were taken by a field-emission transmission electron microscope, HR-AEM (HITACHI FE-2000, Hitachi, Tokyo, Japan); the samples were dispersed in acetone before being placed on carbonic-coated copper grids dropwise before subjecting to the emission.

\subsubsection{EDS (Energy-Dispersive X-ray Spectra)}

The EDS of various Pt catalysts were obtained using XL-40EFG, Philips (Eindhoven, The Netherland). The PANI(EB)/ $\mathrm{Fe}_{3} \mathrm{O}_{4}(\mathrm{OA})$ sample was coated with gold before measurement. 


\subsubsection{Wide-Angled X-ray Diffraction (WXRD)}

A copper target $(\mathrm{Cu}-\mathrm{K} \alpha)$ Rigaku X-ray source (Rigaku, Tokyo, Japan) with a wave-

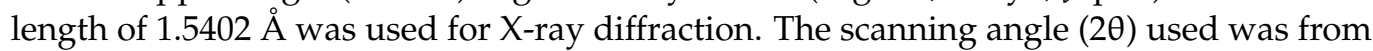
$10^{\circ}$ to $70^{\circ}$ with a voltage of $40 \mathrm{kV}$ and a current of $30 \mathrm{~mA}$, operated at $1^{\circ} \mathrm{min}^{-1}$.

\subsubsection{X-ray Photoelectron Spectroscopy (XPS)}

We applied the different binding energy spectra of N1s of neat PANI(EB) and various iron compounds to characterize various $\mathrm{N}$-containing groups and $\mathrm{Fe}-\mathrm{N}$ covalent bonding after calcination, using the XPS instrument Fison (VG)-Escalab 210 (Fison, Glasgow, UK) and an $\mathrm{Al} \mathrm{Ka} \mathrm{X-ray} \mathrm{source} \mathrm{at} 1486.6 \mathrm{eV}$. The pressure in the chamber was maintained under $10^{-6} \mathrm{~Pa}$ or lower during the measurement. A tablet-like sample was prepared by a stapler.

\subsubsection{Superconductor Quantum Interference Device (SQUID)}

The magnetic properties of various iron compounds were measured by a Quantum Design MPMS-XL7 SQUID magnetometer (ISIS, San Diego, CA, USA)

\section{Results and Discussion}

This section is divided by subheadings. It provides a concise and precise description of the experimental results, their interpretation, as well as the experimental conclusions.

\subsection{Subsection}

\section{FTIR Spectra}

$\mathrm{Fe}_{3} \mathrm{O}_{4}$ nanoparticles prepared by the sol-gel method clearly showed hydroxyl groups at $\sim 3300 \mathrm{~cm}^{-1}$ in accordance with Figure $1 \mathrm{a}$, which did not disappear entirely after esterification with OA, as seen in Figure $1 \mathrm{~b}$. The presence of peaks around $587 \mathrm{~cm}^{-1}$ revealed the formation of $\mathrm{Fe}-\mathrm{O}$ bonding; the symmetric and asymmetric stretching of aliphatic methylene and methyl groups of OA was clearly seen at 2920 and $2840 \mathrm{~cm}^{-1}$.

The prepared $\mathrm{Fe}_{3} \mathrm{O}_{4}$ nanoparticles were mixed with anilinium monomers before inverse emulsion polymerization. The obtained $\mathrm{PANI}(\mathrm{ES}) / \mathrm{Fe}_{3} \mathrm{O}_{4}$ composites were dedoped into PANI(EB) $/ \mathrm{Fe}_{3} \mathrm{O}_{4}$ in $\mathrm{NH}_{4} \mathrm{OH}(\mathrm{aq})$, and their FTIR spectra were compared to those of neat PANI(ES) and PANI(EB), respectively, as shown in Figure 1b. The Fe-O groups were still present in the composites, as shown in Figure 1b, and the characteristic functional groups of PANI belonging either to ES or to EB, were also observed, even when the preparation was carried out in the presence of $\mathrm{Fe}_{3} \mathrm{O}_{4}$, indicating that the characteristic functional groups of PANI were not influenced by the presence of $\mathrm{Fe}_{3} \mathrm{O}_{4}$. However, some interaction occurred between $\mathrm{PANI}(\mathrm{EB})$ and $\mathrm{Fe}_{3} \mathrm{O}_{4}$ particles. For example, peaks belonging neither to neat PANI(EB) nor to $\mathrm{Fe}_{3} \mathrm{O}_{4}$ were observed at around $3160 \mathrm{~cm}^{-1}$, as shown in Figure $1 \mathrm{~b}$. Only single peak found for $-\mathrm{NH}$ - stretch mode $\left(3417 \mathrm{~cm}^{-1}\right)$ of PANI(EB) due to the $\mathrm{H}$ bonds with the $-\mathrm{OH}$ groups of $\mathrm{Fe}_{3} \mathrm{O}_{4}$, as shown in Figure 1a. The presence of $\mathrm{H}$ bonds between PANI(EB) molecules and $\mathrm{Fe}_{3} \mathrm{O}_{4}$ nanoparticles can modify the morphology of PANI(EB) in the composites, which will be examined by UV spectra. 

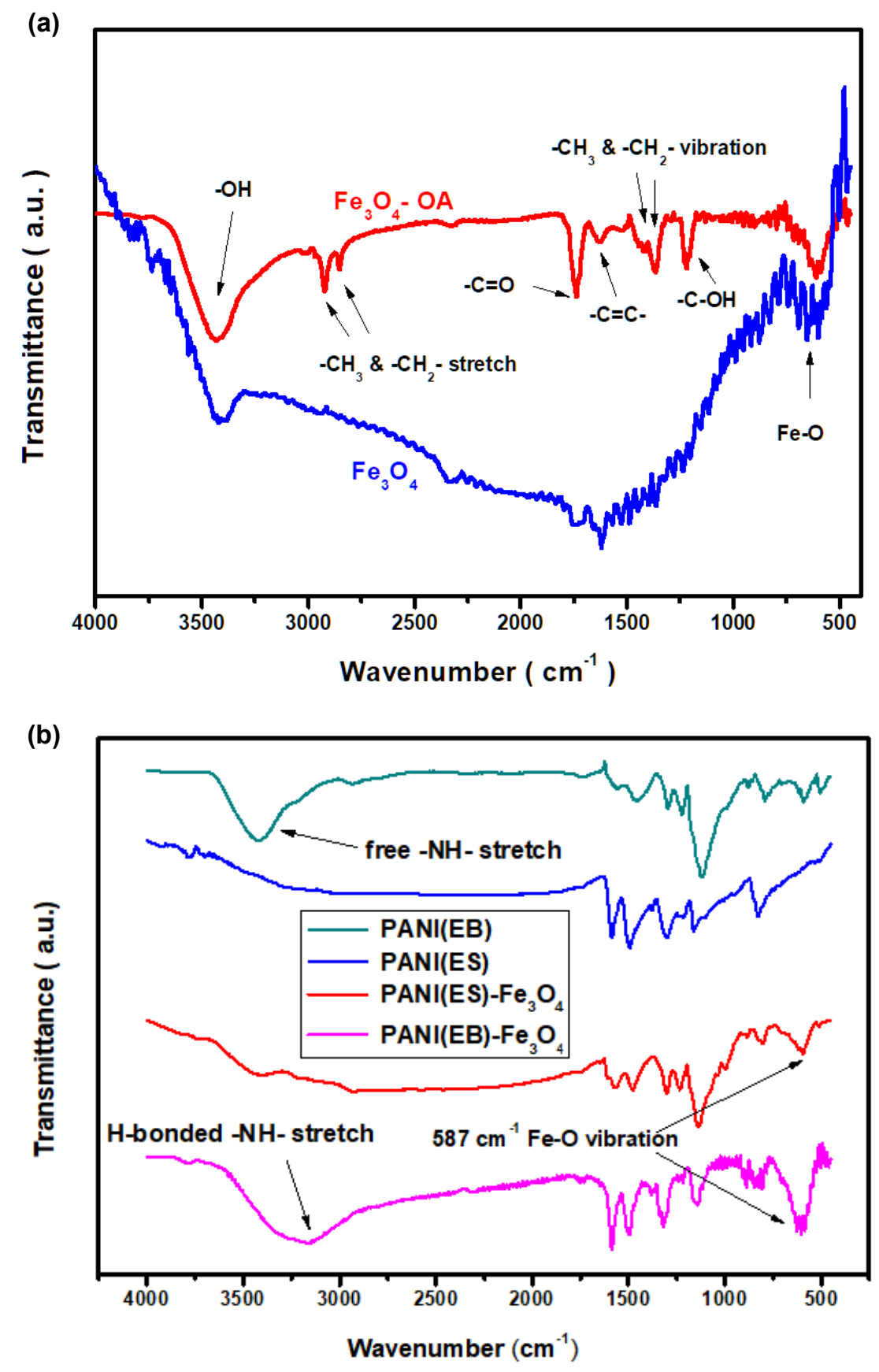

Figure 1. FTIR spectra of (a) $\mathrm{Fe}_{3} \mathrm{O}_{4}$ and $\mathrm{Fe}_{3} \mathrm{O}_{4}(\mathrm{OA})(\mathbf{b}) \mathrm{PANI}$ and PANI/ $\mathrm{Fe}_{3} \mathrm{O}_{4}$.

\subsection{UV-Vis Spectra}

The UV spectra of neat PANI and composites prepared with either common or inverse emulsion polymerization are shown in Figure 2. For neat PANI(Em) and PANI(ES), the so-called 'free carrier tail' [28,29], which is related to the increase of the conjugation chain length and super red-shift to the near-IR region due to the more extended PANI molecules, is demonstrated in Figure 2. After $\mathrm{Fe}_{3} \mathrm{O}_{4}$ nanoparticles were incorporated in PANI, the tails in the near-IR region decayed and became curved for samples prepared by both regular and inverse emulsion. The bended curves of the composites indicate the shortening of the conjugation (blue shift). The extended PANI molecules recoiled back appearing like random coils than rigid rods. The coiling driving force could originate from the H-bonding between the hydroxyl groups of $\mathrm{Fe}_{3} \mathrm{O}_{4}$ nanoparticles and the amino groups of PANI. For $\mathrm{PANI}(\mathrm{Em}) / \mathrm{Fe}_{3} \mathrm{O}_{4}$ prepared with the regular emulsion approach, the $\mathrm{H}$-bonding mainly 
occurred on the rigid rod surfaces, and the nanoparticles remained on the surface, as described in Scheme 2, since the hydrophilic $\mathrm{Fe}_{3} \mathrm{O}_{4}$ nanoparticles would remain in the water phase rather than penetrate in the core of the micelles where polymerization occurred (Scheme 2).

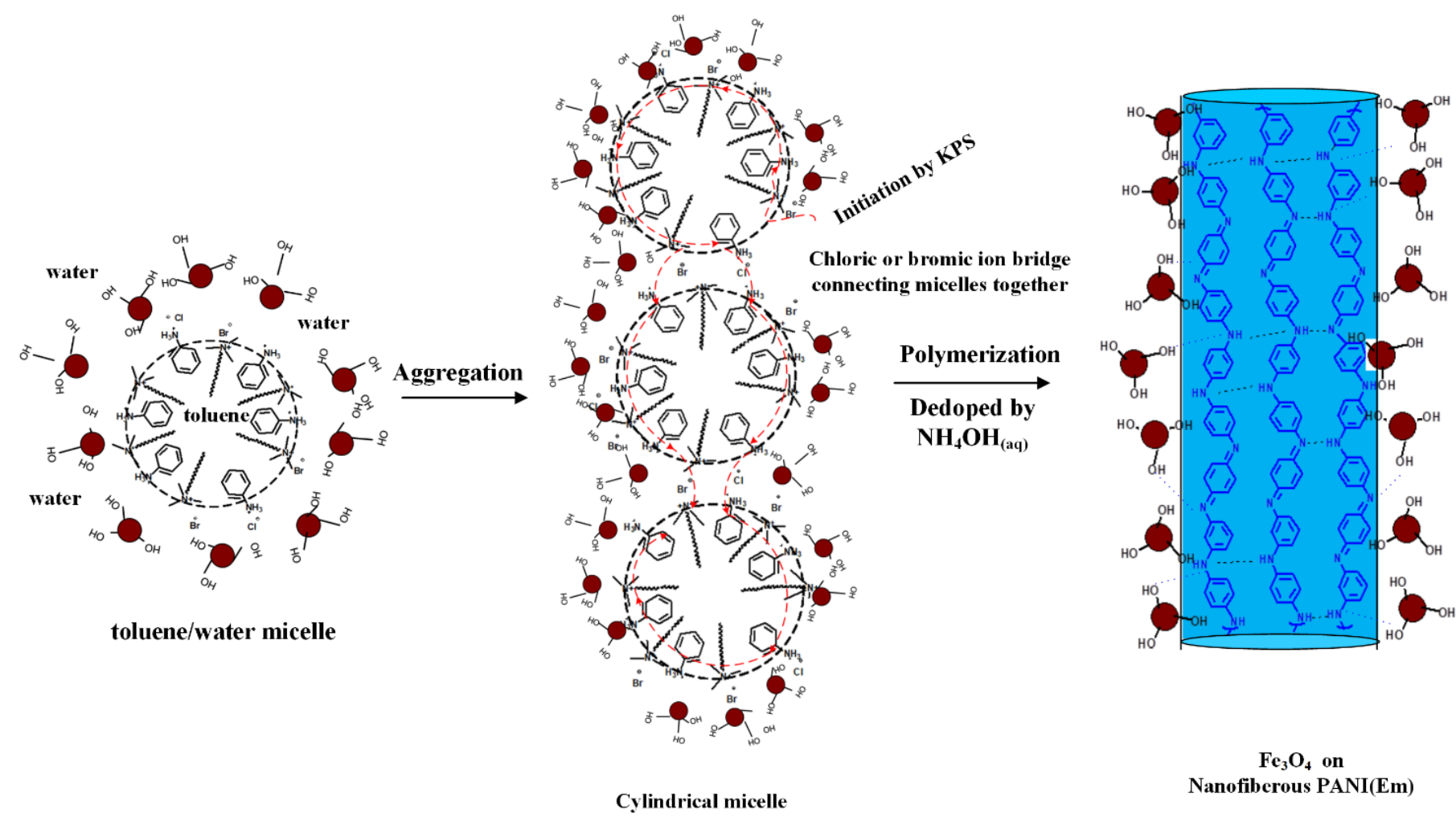

Scheme 2. Preparation of the PANI(Em) $/ \mathrm{Fe}_{3} \mathrm{O}_{4}$ composite via regular emulsion polymerization.

PANI(ES) $/ \mathrm{Fe}_{3} \mathrm{O}_{4}(\mathrm{OA})$ prepared with inverse emulsion also demonstrated a blue shift from the near-IR $(890 \mathrm{~nm})$ to the visible region $(620 \mathrm{~nm})$ for the $\lambda_{\max }$, revealing that hydroxylated $\mathrm{Fe}_{3} \mathrm{O}_{4}$ nanoparticles were able to enter the micelles where they were surrounded by the coiled PANI(ES) molecules after polymerization to de-dope polyaniline producing PANI(EB). The $\mathrm{Fe}_{3} \mathrm{O}_{4}(\mathrm{OA})$ nanoparticles with surface-OH groups and only one oleic tail (based on the molar ratio described in Section 2.1.4) were capable of staying in the outer area of the micelles, where most of the anilinium monomers were located (Scheme 3) during the inverse emulsification process, covered by the coiled PANI(ES) after polymerization. Therefore, the significant blue shift of PANI(ES)/ $\mathrm{Fe}_{3} \mathrm{O}_{4}(\mathrm{OA})$ in the UV spectrum of Figure 2 came from the neutralization effect after contact with $\mathrm{Fe}_{3} \mathrm{O}_{4}(\mathrm{OA})$, which turned PANI(ES) $/ \mathrm{Fe}_{3} \mathrm{O}_{4}(\mathrm{OA})$ to PANI(EB) $/ \mathrm{Fe}_{3} \mathrm{O}_{4}(\mathrm{OA})$, as depicted in Scheme 3. In contrast, the curve of the UV spectrum of $\mathrm{PANI}(\mathrm{Em}) / \mathrm{Fe}_{3} \mathrm{O}_{4}$ prepared via regular emulsion polymerization only demonstrated a slightly bending curve in the near-IR region after the introduction of $\mathrm{Fe}_{3} \mathrm{O}_{4}$, because the obtained PANI rods were just covered by the $\mathrm{Fe}_{3} \mathrm{O}_{4}$ nanoparticles, as will be seen and discussed in the following SEM section. 


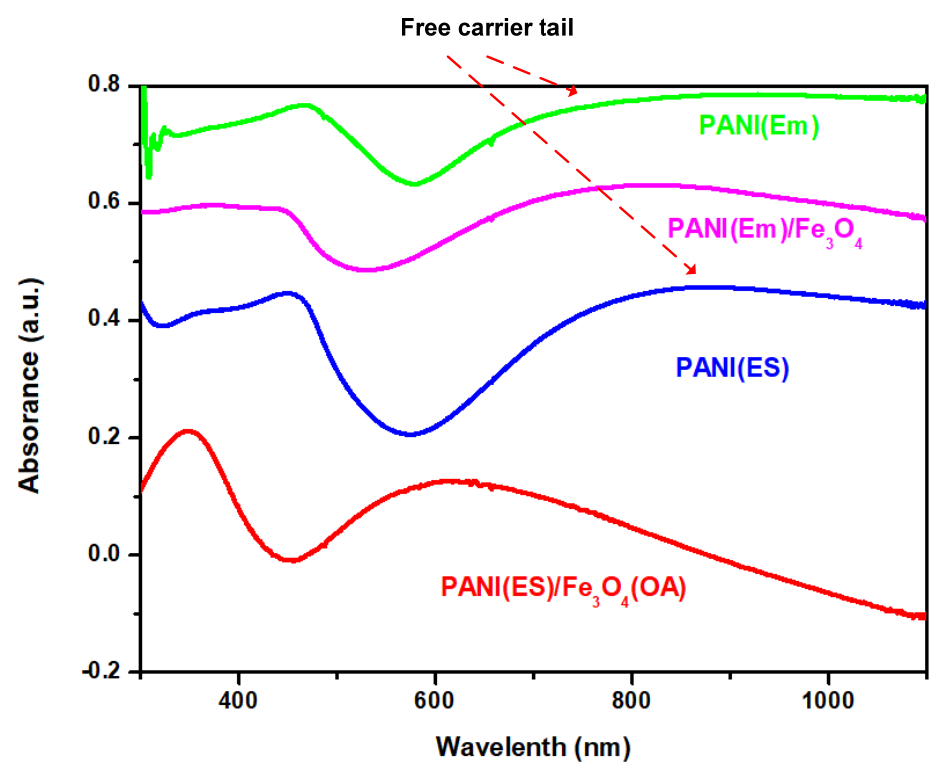

Figure 2. UV-Vis-NIR spectra of various PANIs.

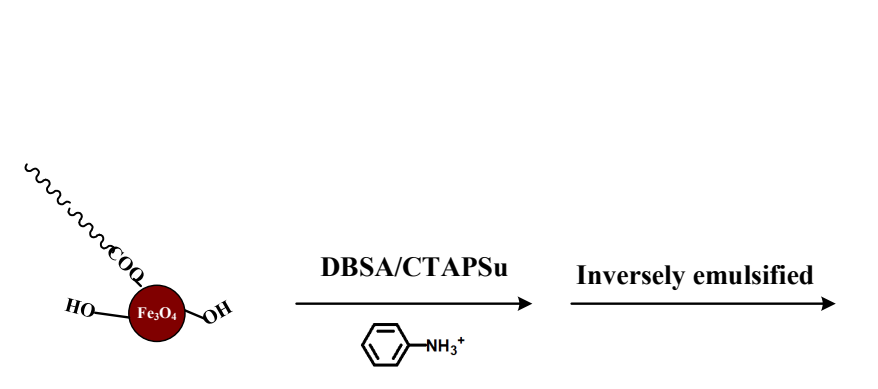
Very few hydrophobic
CTAPSu initiators can diffuse
into inverse micelle

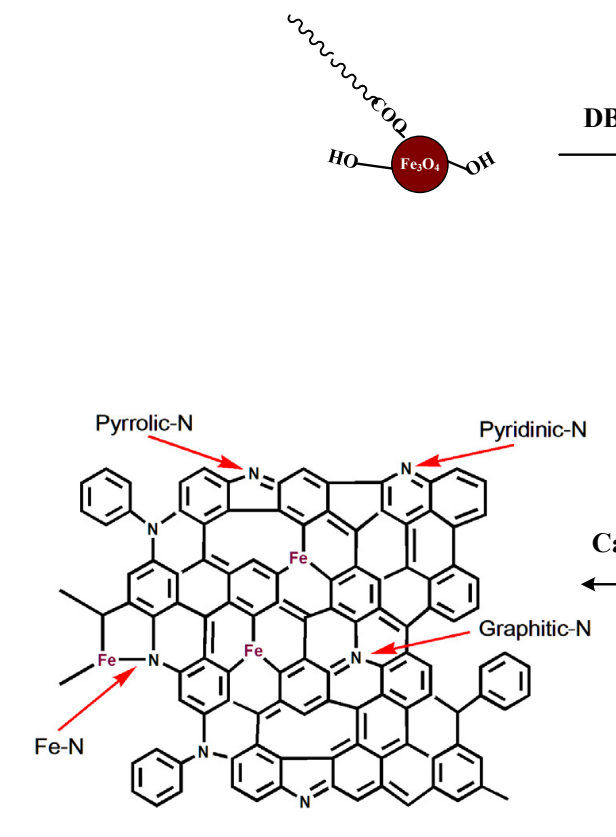

FeNC(OA)

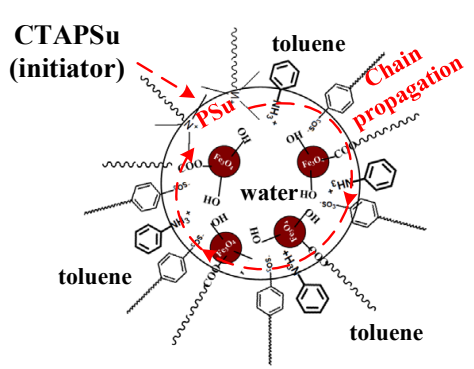

water/toluene micelle
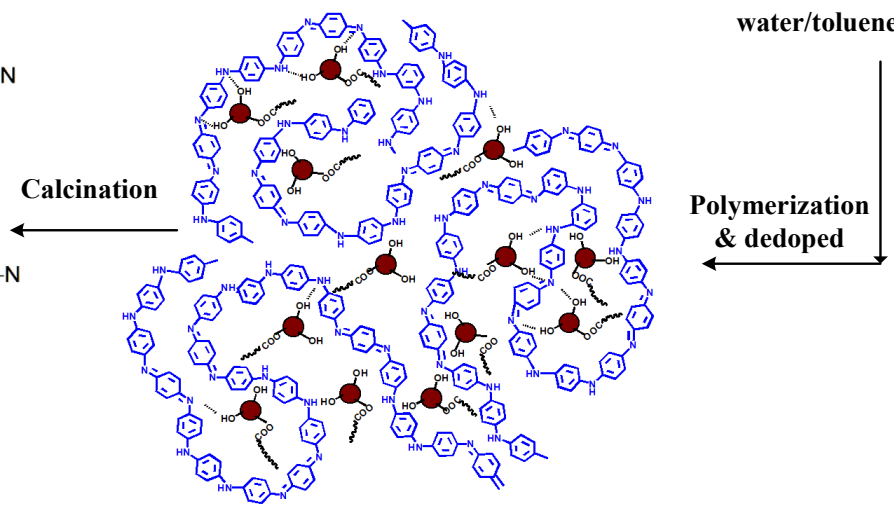

Scheme 3. Preparation of the PANI/ $\mathrm{Fe}_{3} \mathrm{O}_{4}(\mathrm{OA})$ composite via inverse emulsion polymerization.

\subsection{TGA}

The thermal degradation of PANI(EB) $/ \mathrm{Fe}_{3} \mathrm{O}_{4}(\mathrm{OA})$ was monitored by TGA. We observed about $5 \mathrm{wt} \%$ loss, as shown in Figure 3, due to the evaporation of water below $100{ }^{\circ} \mathrm{C}$. A not significant weight loss was measured from 100 to $300^{\circ} \mathrm{C}$ [15]. Crosslinking between neighboring PANI(EB) occurred at this stage, leading to the loss of only some $\mathrm{H}$ elements without causing significant weight loss as would result from breaking the 
backbones. After $300{ }^{\circ} \mathrm{C}$, significant thermal degradation of PANI(EB) main chains and alkyl chains of OA occurred, and the matrix started to carbonize by driving some $\mathrm{N}$ element off in the form of ammonia and methane. The carbonized matrix became robust $\mathrm{Fe}, \mathrm{N}$-doped carbonaceous composites after $500{ }^{\circ} \mathrm{C}$, and weight loss was negligible up to $1000{ }^{\circ} \mathrm{C}$. Eventually, a residual weight of $35 \%$ was measured, which is well above the theoretical value of iron, indicating some of the PANI(EB) was retained in the form of a Fe, $\mathrm{N}$-doped composite after calcination, as described in the final portion of Scheme 3.

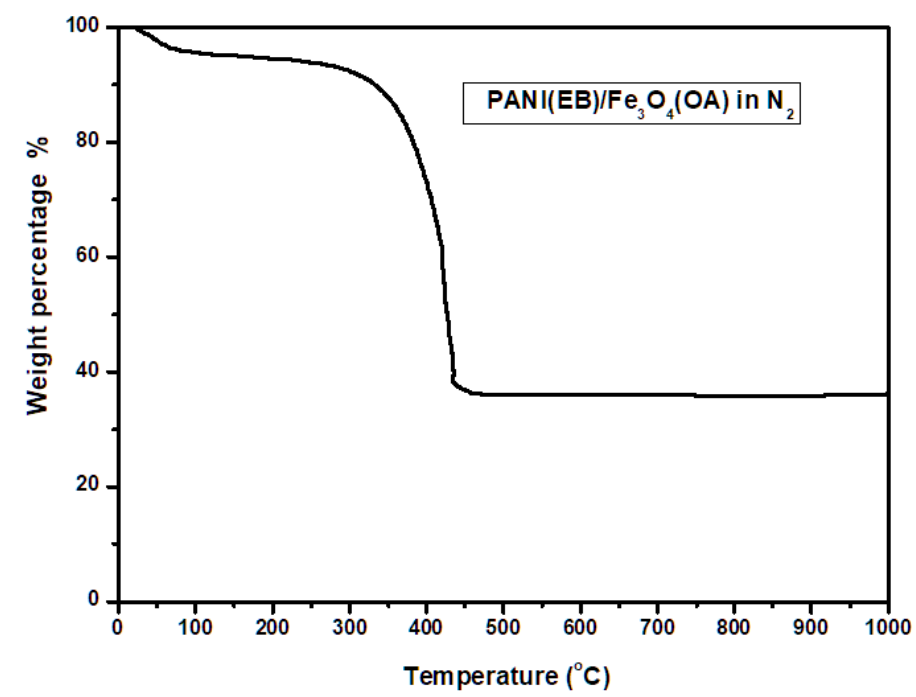

Figure 3. TGA thermogram of $\mathrm{PANI}(\mathrm{EB}) / \mathrm{Fe}_{3} \mathrm{O}_{4}(\mathrm{OA})$.

\subsection{SEM}

For PANI(EB) prepared with the regular emulsion approach, a nanofibrous morphology was clearly observed in SEM micro-pictures (Figure 4a). The nanofibrous morphology originated from the interconnection of micelles by counter ions before polymerization [28], resulting in the rigid-rod morphology after polymerization, which is commonly found in the emulsion polymerization of PANI, as described in Scheme 1 [29].

Due to their hydrophilic nature, hydroxylated $\mathrm{Fe}_{3} \mathrm{O}_{4}$ particles (referring to the FTIR spectrum in Figure 1) would remain outside the micelles in the water phase before and after the polymerization, covering the rigid-rod surfaces of PANI eventually (Figure $4 \mathrm{~b}$ ). Comparing the sizes of the PANI nanofibers without and with $\mathrm{Fe}_{3} \mathrm{O}_{4}$ particles (Figure 4a,b) present during polymerization, the diameter of the PANI nanofibers increased from 100 to $200 \mathrm{~nm}$ when many $\mathrm{Fe}_{3} \mathrm{O}_{4}$ particles covered on fibers' surface.

However, $\mathrm{PANI}(\mathrm{Em}) / \mathrm{Fe}_{3} \mathrm{O}_{4}$ obtained from common emulsion was only covered with $\mathrm{Fe}_{3} \mathrm{O}_{4}$ nanoparticles, which can be easily converted to ferrite after calcination, and the unprotected ferrite can be easily oxidized into either $\mathrm{Fe}_{3} \mathrm{O}_{4}$ or cementite when exposed to the open air; in addition, the lower magnetization can largely decrease the bulk magnetization of the calcined iron composites. In other words, the iron-enriched ferrite composite with a high magnetic moment needs the protection of a calcined PANI covering to prevent the oxidation or the diffusion of carbon into the ferrite matrix, resulting in the formation of cementite. The evidence of the conversion from ferrite to either cementite or oxidized $\mathrm{Fe}_{3} \mathrm{O}_{4}$ was provided by the X-ray diffraction patterns of the calcined products.

Both $\mathrm{Fe}_{3} \mathrm{O}_{4}$ and $\mathrm{Fe}_{3} \mathrm{O}_{4}(\mathrm{OA})$ particles demonstrated a connected pearl-like morphology, as shown in Figure 4c,d. The strong interaction (mainly H-bonding) between these particles and anilinium monomers in the outer area of the micelles during inverse emulsification allowed the obtained PANI molecules to adopt a curved conformation with a reduced crystalline structure. The rigid-rod morphology was no more seen in either $\mathrm{PANI}(\mathrm{EB}) / \mathrm{Fe}_{3} \mathrm{O}_{4}$ or PANI(EB) $/ \mathrm{Fe}_{3} \mathrm{O}_{4}(\mathrm{OA})$ and was mostly replaced by particular morphologies, in accordance with Figure $4 \mathrm{e}, \mathrm{f}$ and as described in Scheme 3. The calcined composites (FeNC) demonstrated a largely curved slab-like morphology due to the gradual carbonization of 
the polyaniline matrix with the proceeding of calcination, which fused the smaller particles into huge slabs, as seen in Figure $4 \mathrm{~g}$.
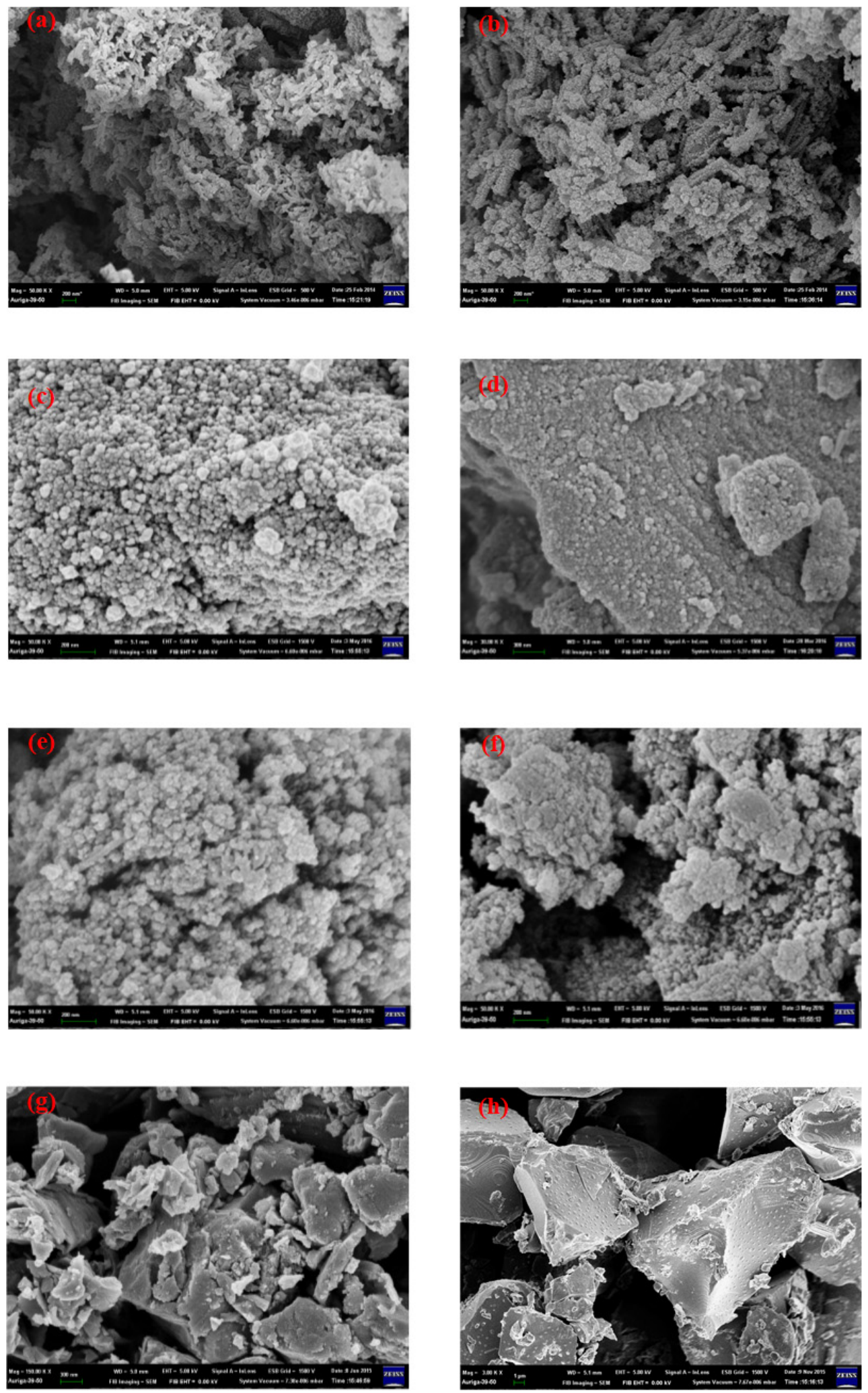

Figure 4. SEM micro-pictures of PANI and various iron compounds (a) PANI(Em) (b) PANI(Em)/ $\mathrm{Fe}_{3} \mathrm{O}_{4}$ (c) $\mathrm{Fe}_{3} \mathrm{O}_{4}$ (d) $\mathrm{Fe}_{3} \mathrm{O}_{4}(\mathrm{OA})$ (e) PANI(EB) $/ \mathrm{Fe}_{3} \mathrm{O}_{4}$ (f) PANI(EB) $/ \mathrm{Fe}_{3} \mathrm{O}_{4}(\mathrm{OA})$ (g) $\mathrm{FeNC}$ (h) $\mathrm{FeNC}(\mathrm{OA})$. 


\subsection{TEM Micropictures}

Similar to the SEM micro-pictures in Figure 4, the TEM micro-pictures of neat $\mathrm{Fe}_{3} \mathrm{O}_{4}$ and $\mathrm{Fe}_{3} \mathrm{O}_{4}(\mathrm{OA})$ demonstrated the presence of pearl-like nanoparticles with similar sizes, as seen by comparing Figure $5 \mathrm{a}$ with Figure $5 \mathrm{~b}$. The presence of OA during the preparation of $\mathrm{Fe}_{3} \mathrm{O}_{4}$ seemed to fasten the aggregation of the nanoparticles, as shown in Figure $5 \mathrm{~b}$. The same phenomenon can be seen in Figure $5 \mathrm{c}$, d for PANI $/ \mathrm{Fe}_{3} \mathrm{O}_{4}$ and $\mathrm{PANI} / \mathrm{Fe}_{3} \mathrm{O}_{4}(\mathrm{OA})$ mixtures which were obtained via inverse emulsion polymerization. The graft of $\mathrm{OA}$ on $\mathrm{Fe}_{3} \mathrm{O}_{4}\left(\mathrm{Fe}_{3} \mathrm{O}_{4}(\mathrm{OA})\right)$ surfaces stabilized the micelle and allowed more $\mathrm{Fe}_{3} \mathrm{O}_{4}$ nanoparticles in the micelles. Besides, the swelling micelles resulting from the larger and more stable polymerizing PANI molecules (polymer droplets), prevented the early precipitation of PANI $/ \mathrm{Fe}_{3} \mathrm{O}_{4}(\mathrm{OA})$ from the broken polymer droplets, as described in Scheme 3.

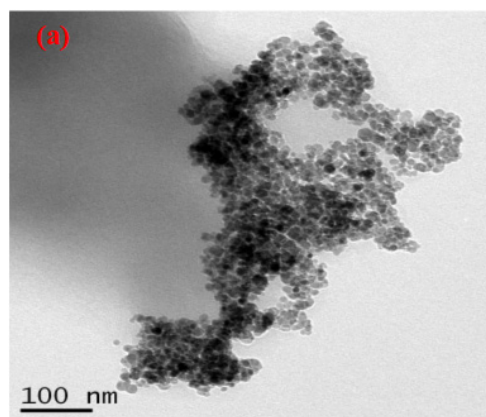

(d)
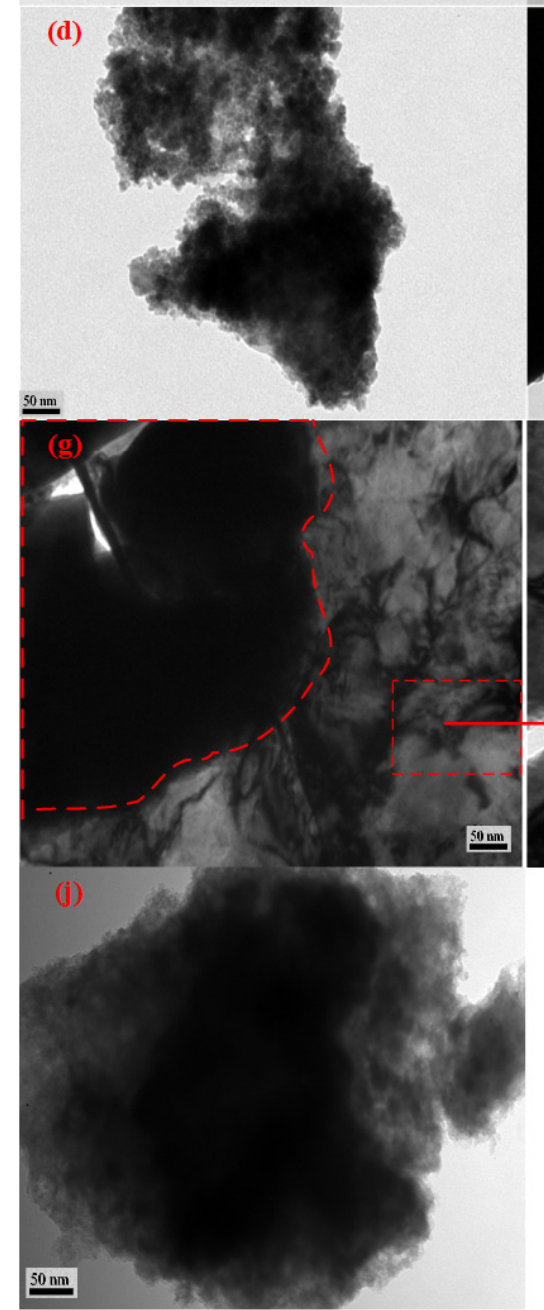
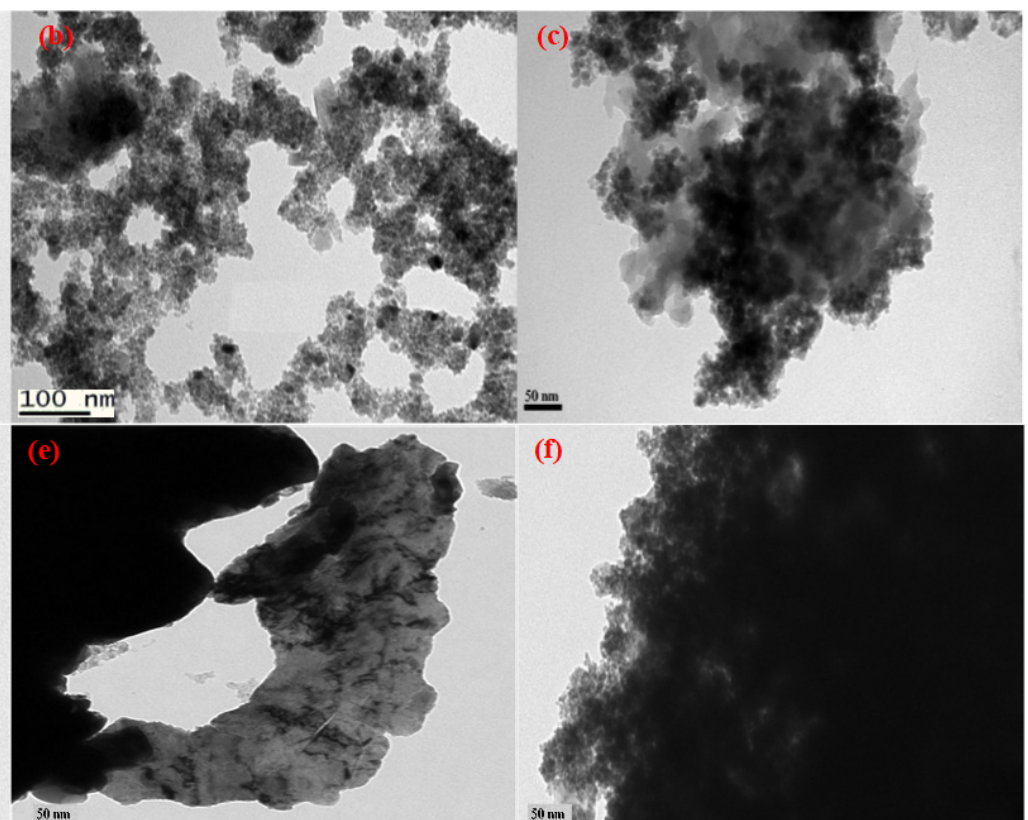

(f)
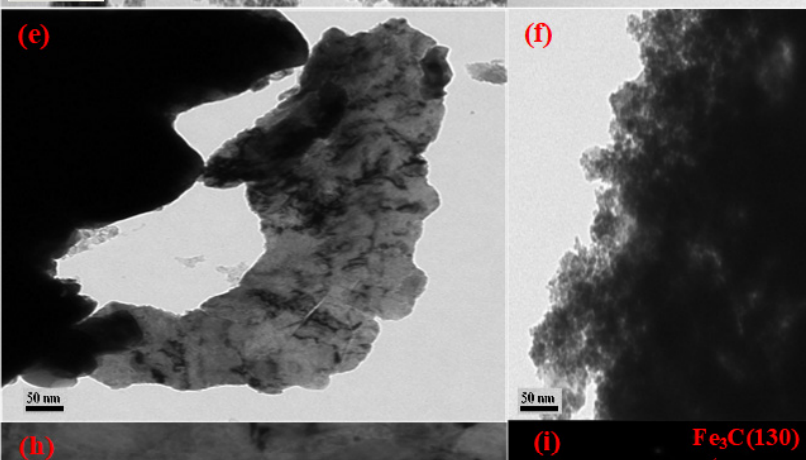

$\mathrm{Fe}_{3} \mathrm{C}(130$

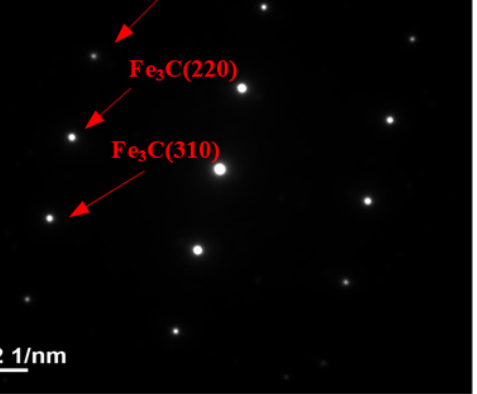

$\underline{21 / \mathrm{nm}}$

Figure 5. TEM micro-pictures of (a) $\mathrm{Fe}_{3} \mathrm{O}_{4}$ (b) $\mathrm{Fe}_{3} \mathrm{O}_{4}(\mathrm{OA})$ (c) $\mathrm{PANI}(\mathrm{EB}) / \mathrm{Fe}_{3} \mathrm{O}_{4}$ (d) PANI(EB)/ $\mathrm{Fe}_{3} \mathrm{O}_{4}(\mathrm{OA})(\mathbf{e}) \mathrm{FeNC}(\mathbf{f})$ FeNC(OA) (g) FeNC-2 (h) FeNC-2 (enlarged) (i) e-diffraction pattern of vein-like texture (j) FeNC(OA)-2. 
After calcination at $950{ }^{\circ} \mathrm{C}$, all pearl-like $\mathrm{Fe}_{3} \mathrm{O}_{4}$ particles disappeared and fused into clusters (Figure 5e,f) due to the carbonization of polyaniline matrix. Possibly, some of the $\alpha$-Fe would converted to $\mathrm{Fe}_{3} \mathrm{C}$, combining with the carbon provided by PANI during calcination, developing into a veined texture, present around or inside a dark cluster, as shown in Figure $5 \mathrm{e}$ for FeNC. However, for FeNC(OA) (Figure $5 \mathrm{f}$ ), almost no veined texture in the dark cluster could be seen after calcination, indicating the formed $\alpha$-Fe was well mixed with $\mathrm{Fe}_{3} \mathrm{C}$, which has a very dense structure and can effectively hinder $\mathrm{O}_{2}$ from diffusing into the $\alpha$-Fe domains and maintain its high magnetic moment.

The density of $\mathrm{Fe}_{3} \mathrm{C}$ is $7.69 \mathrm{gcm}^{-3}$, which is almost equivalent to that of $\alpha-\mathrm{Fe}\left(7.87 \mathrm{~g} \mathrm{~cm}^{-3}\right)$, scattering TEM electrons equally. Therefore, most of the $\alpha$-Fe are staying with some $\mathrm{Fe}_{3} \mathrm{C}$ in the dark area of TEM pictures of FeNCs, whose vein texture are not perceivable due to the similar electron scattering capability. The two types of iron compounds $(\alpha-\mathrm{Fe} /$ and $\mathrm{Fe}_{3} \mathrm{C}$ ) were the dominant species, and less $\mathrm{Fe}_{3} \mathrm{O}_{4}$ (density is $5.17 \mathrm{gcm}^{-3}$ ) was present after calcination at $950{ }^{\circ} \mathrm{C}$, based on the following discussions on the $\mathrm{X}$-ray diffraction and SQUID spectra.

The morphology of FeNC changed gradually, and more veined textures of $\mathrm{Fe}_{3} \mathrm{C}$ appeared after two months in the atmosphere, as observed when comparing Figure 5e with Figure $5 \mathrm{~g}$ or Figure $5 \mathrm{~h}$. The e-diffraction pattern demonstrated in Figure 5i clearly shows the vein-like textures contributed by $\mathrm{Fe}_{3} \mathrm{C}$. Obviously, the unprotected $\alpha$-Fe of FeNC could be converted into $\mathrm{Fe}_{3} \mathrm{C}$ gradually even at room temperature if it stayed in the atmosphere for enough time. Eventually, the magnetization of FeNC-2 would decrease by sacrificing $\alpha-$ $\mathrm{Fe}_{\text {to }} \mathrm{Fe}_{3} \mathrm{C}$, which we will discuss in the following X-ray diffraction and SQUID. However, for FeNC(OA), the morphology was almost the same after two months, as seen when we compare Figure $5 \mathrm{f}$ with Figure $5 \mathrm{j}$. The vein-like morphology around the dark cluster was not significant, as shown in Figure $5 \mathrm{j}$, indicating that $\alpha$-Fe was still the dominant species in the dark cluster, maintaining its high magnetic moment. The presence of some $\mathrm{Fe}_{3} \mathrm{C}$ in the dark cluster can protect the FeNC(OA) from oxidation during long-term exposure to the open air. It is still possible that some of the $\alpha$-Fe will be oxidized to $\mathrm{Fe}_{3} \mathrm{O}_{4}$ after long-time exposure in the open air if the protecting $\mathrm{Fe}_{3} \mathrm{C}$ is phase-separated from the dark cluster, leaving the vulnerable $\alpha$-Fe to $\mathrm{O}_{2}$, like FeNC and FeNC-2, which will be confirmed and discuss later.

\subsection{EDS}

The EDS spectrum of $\mathrm{FeNC}(\mathrm{OA})$ and its element mappings are illustrated in Figure $6 \mathrm{a}, \mathrm{b}$, respectively. Figure 6a clearly demonstrates the presence of $\mathrm{Fe}, \mathrm{N}$, and $\mathrm{C}$ elements, $\mathrm{C}$ is the dominant element, and both $\mathrm{Fe}$ and $\mathrm{N}$ peaks are clearly seen. The sulfur element derived from KPS, which was converted to sulfate ion after initiating the polymerization of polyaniline. The element mappings demonstrated in Figure $6 \mathrm{~b}$ revealed the presence of $\mathrm{Fe}, \mathrm{N}$, and $\mathrm{C}$ elements (in the form of $\alpha-\mathrm{Fe}, \mathrm{Fe}_{4} \mathrm{~N}$, or $\mathrm{Fe}_{3} \mathrm{C}$ ), uniformly distributed in the carbonaceous matrix. The sulfur in Figure 6a came from the sulfate salt which formed from APS after initiating the polymerization of aniline salts. 
(a)

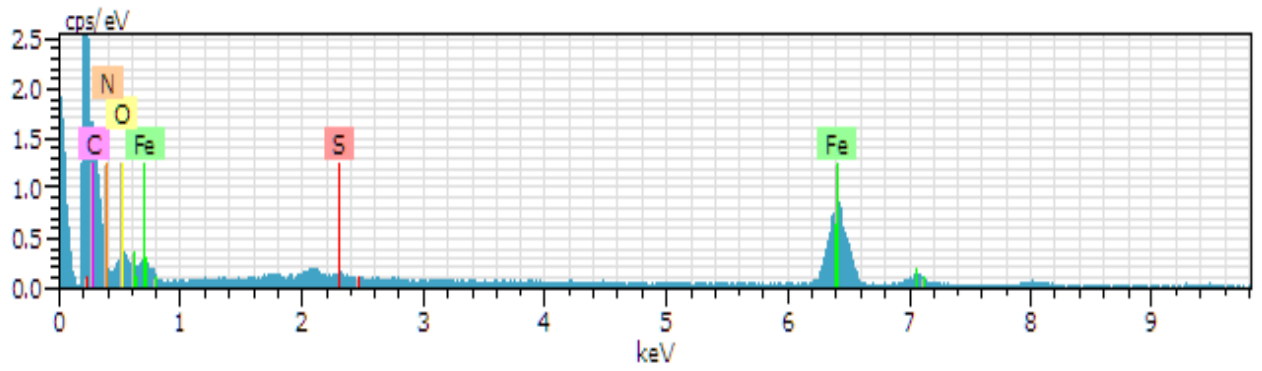

(b)

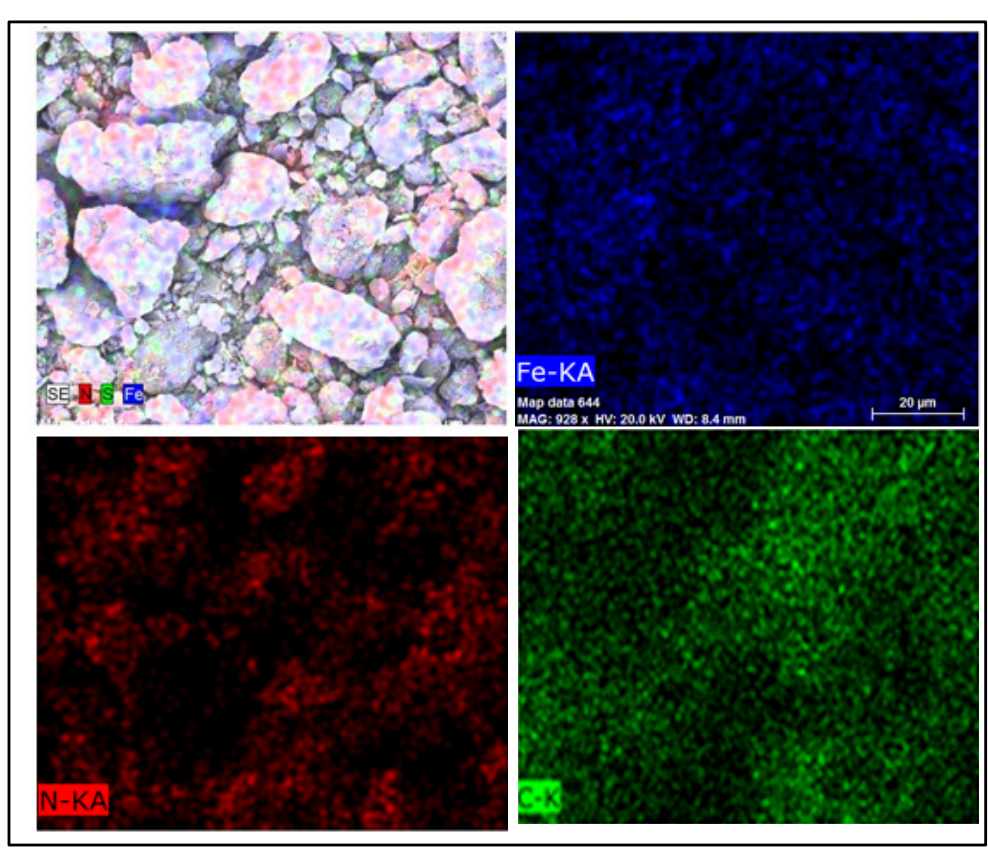

Figure 6. EDS (a) spectrum (b) Fe, $\mathrm{N}$, and $\mathrm{C}$ mapping of $\mathrm{FeNC}(\mathrm{OA})$.

\subsection{XRD Patterns}

The X-ray diffraction patterns of neat PANI(EB) and nano- $\mathrm{Fe}_{3} \mathrm{O}_{4}$ compounds are displayed in Figure 7a, which demonstrates the crystalline patterns of polyaniline and $\mathrm{Fe}_{3} \mathrm{O}_{4}$ before and after mixing via polymerization. The pattern of neat $\mathrm{Fe}_{3} \mathrm{O}_{4}$ matches well with the standard pattern of $\mathrm{Fe}_{3} \mathrm{O}_{4}$ (JCPDS, No. 89-4319); smoother curves were found in the spectrum, indicating higher crystallinity. A clear pattern of peaks smaller than $30^{\circ}(2 \theta)$ were seen for neat PANI(EB) due to the high degree of crystallization. However, peaks with some noise signals were present in the patterns of composite materials, especially after $\mathrm{Fe}_{3} \mathrm{O}_{4}$ was modified by $\mathrm{OA}$ before polymerization. Usually, $\mathrm{Fe}_{3} \mathrm{O}_{4}$ crystals are easily destroyed when a long-tail molecule like $\mathrm{OA}$ is attached on the surface, which might contribute to the imperfect diffracted pattern seen in the spectrum. Besides, no significant characteristic diffraction peak was found for PANI in PANI(EB) $/ \mathrm{Fe}_{3} \mathrm{O}_{4}(\mathrm{OA})$ composites, indicating that the crystalline structure of PANI(EB) in the PANI(EB) $/ \mathrm{Fe}_{3} \mathrm{O}_{4}(\mathrm{OA})$ was almost entirely demolished by the presence of $\mathrm{Fe}_{3} \mathrm{O}_{4}(\mathrm{OA})$ nanoparticles in the micelles.

Significant peaks at $44^{\circ}$ of $\alpha$-Fe are visible in the X-ray spectra of Figure $6 \mathrm{~b}$ after calcination at $950{ }^{\circ} \mathrm{C}$ for all iron-nanocomposites, contributing to the excellent high Ms $\left(>120 \mathrm{emu} \mathrm{g}^{-1}\right.$ ), which will be discussed later. 

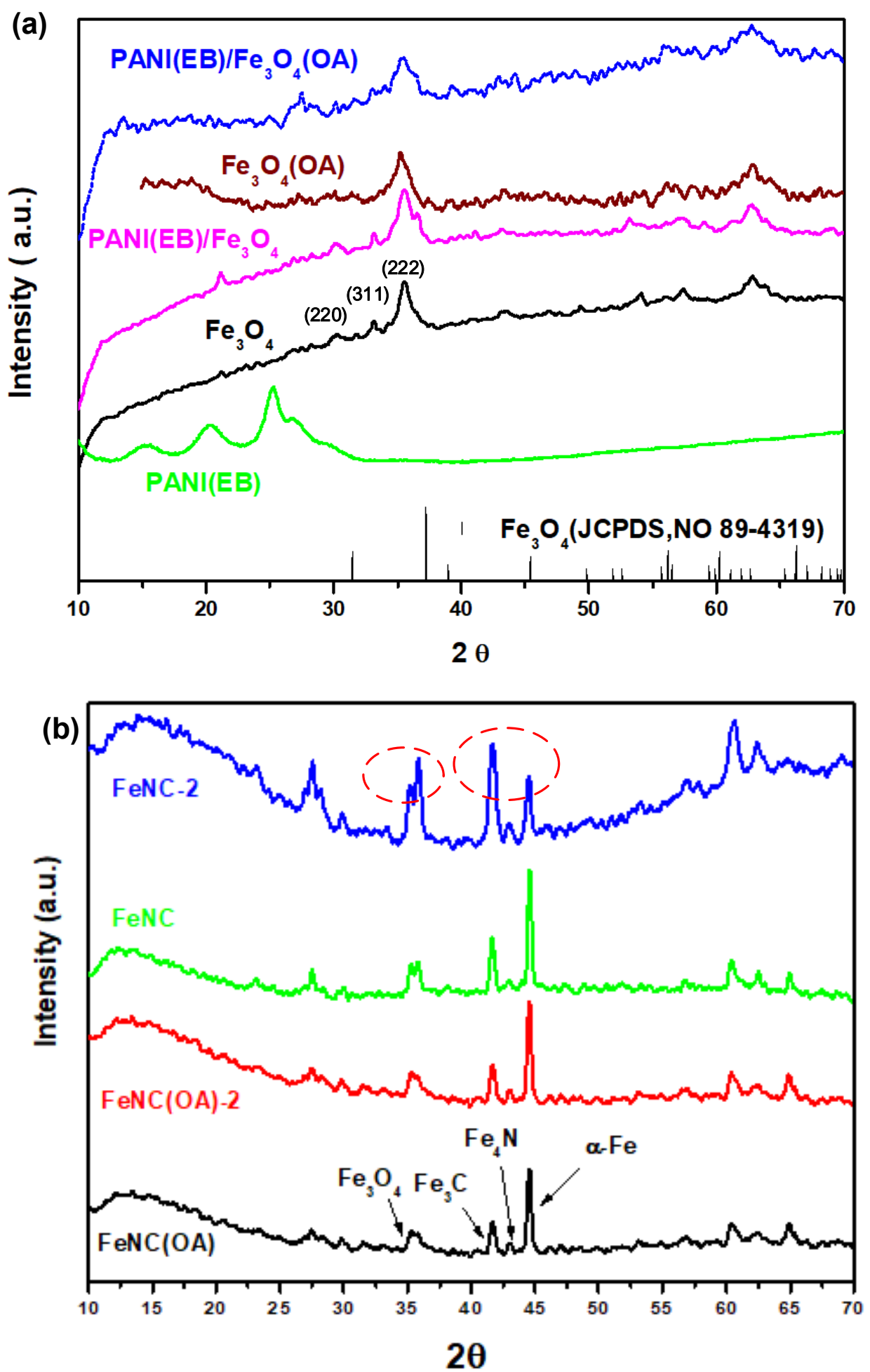

Figure 7. X-ray diffraction patterns of (a) PANI and iron compounds before calcination (b) iron compounds after calcination.

These peaks are characteristic diffraction peaks of cementite $\left(\mathrm{Fe}_{3} \mathrm{C}\right)$ and ferrite $(\alpha-\mathrm{Fe})$, respectively, with a higher Ms than $120 \mathrm{emu} \mathrm{g}^{-1}$, even reaching $197 \mathrm{emu} \mathrm{g}^{-1}$ for $\alpha$-Fe. The magnetic moment contributed from $\mathrm{Fe}_{3} \mathrm{C}$ could be retained for a long time due to the perfect, hard crystalline structure, which could effectively prevent further oxidation in the atmosphere. However, $\alpha-\mathrm{Fe}$, which is made of pure Fe element, can easily be oxidized or converted to other iron compounds with weaker magnetization if it stays in the atmosphere for a long time. For example, soft $\alpha$-Fe can combine with oxygen in the 
air and become $\mathrm{Fe}_{3} \mathrm{O}_{4}$ (oxidation) again, and the carbons close to $\alpha$-Fe can also diffuse into the soft $\alpha$-Fe matrix and create the harder crystalline structure of $\mathrm{Fe}_{3} \mathrm{C}$. Both types of reactions turn out to be products with a lower magnetic moment compared to $\alpha$-Fe and would significantly decrease the bulk magnetization. When we compared the $\mathrm{X}$-ray diffraction patterns obtained two months later with the original one (Figure $7 \mathrm{~b}$ ), we noticed that iron composite prepared with neat $\mathrm{Fe}_{3} \mathrm{O}_{4}(\mathrm{FeNC})$ could develop into a compound with more $\mathrm{Fe}_{3} \mathrm{O}_{4}$ and $\mathrm{Fe}_{3} \mathrm{C}\left(42^{\circ}\right)$. Based on the TEM micro-pictures (Figure $5 \mathrm{~g}$, $\mathrm{h}$ ), we found many veined textures developed only by the sides of FeNC-2 after two months.

The TEM picture (Figure 5j) shows that no significant $\mathrm{Fe}_{3} \mathrm{C}$ precipitated from the matrix compound during two month in the air, indicating some hard, perfect crystallized $\mathrm{Fe}_{3} \mathrm{C}$ mixed with $\alpha$-Fe can effectively prevent oxidation from losing its magnetic moment.

\subsection{XPS Spectra}

The XPS of $\mathrm{N}_{1 \mathrm{~s}}$ of neat PANI(EB), FeNC, and FeNC(OA) are illustrated in Figure 8 and characterize the possible $\mathrm{N}$-containing products after calcination. In Figure $8 \mathrm{a}$, no complicated N-related groups are seen, but quinoid-N and benzenoid-N are observed, which are connected alternatively to become PANI(EB). However, various $\mathrm{N}$-containing groups [30-32] include pyridinic $\mathrm{N}$ (six-membered ring present in the edge), pyrrolic $\mathrm{N}$ (five-membered ring present on the edge), graphitic $\mathrm{N}$ (six-membered ring present in the middle of graphene-like matrix), and $\mathrm{Fe}-\mathrm{N}$ emerged after calcination at $950{ }^{\circ} \mathrm{C}$, and are depicted in the last portion of Scheme 3. Both FeNC (Figure 8b) and FeNC(OA) (Figure 8c) contain a large quantity of pyrrolic $\mathrm{N}$ and less graphitic $\mathrm{N}$.

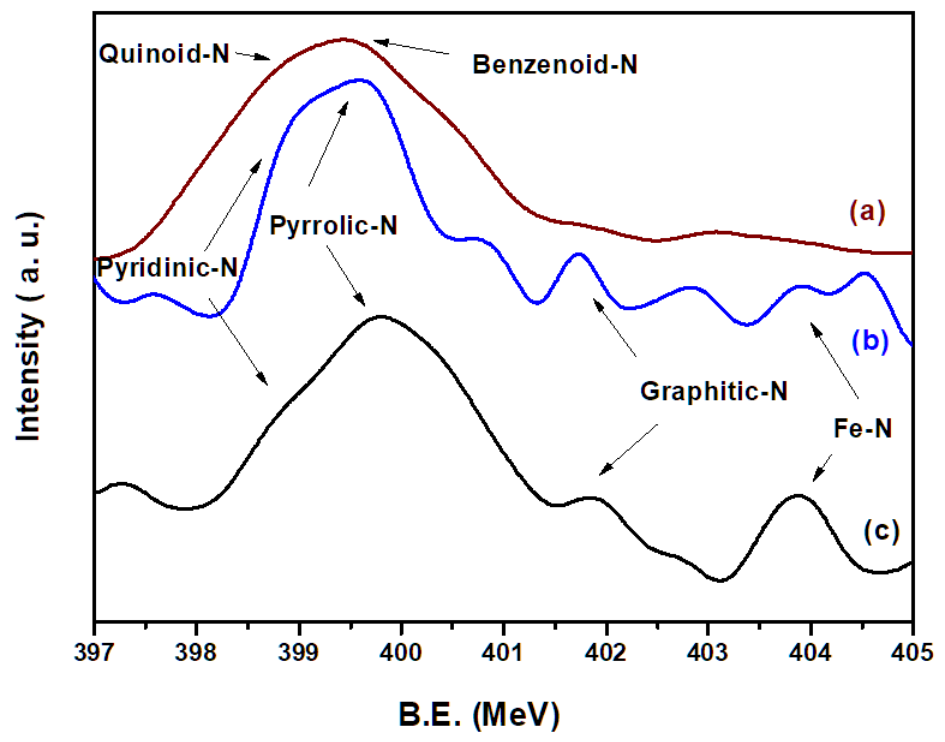

Figure 8. XPS spectra of $\mathrm{N}_{1 \mathrm{~s}}$ of (a) PANI(EB) (b) FeNC (c) FeNC(OA).

\subsection{SQUID Spectra}

Calcination above $900{ }^{\circ} \mathrm{C}$ for the blended mixtures of polyaniline and nano- $\mathrm{Fe}_{3} \mathrm{O}_{4}$ provided enough energy for the movement of various elements including $\mathrm{Fe}, \mathrm{N}, \mathrm{C}$, and $\mathrm{O}$. The arrangement of these elements created a new form of iron-related compounds. All of them demonstrated much higher Ms than the original $\mathrm{Fe}_{3} \mathrm{O}_{4}$ and contributed to the high Ms due to the presence of $\mathrm{Fe}_{3} \mathrm{C}, \mathrm{Fe}_{4} \mathrm{~N}$, and $\alpha$ - $\mathrm{Fe}$ in the calcined composites.

As expected, FeNC and $\mathrm{FeNC}(\mathrm{OA})$, which were obtained from the calcination of $\mathrm{PANI}(\mathrm{EB}) / \mathrm{Fe}_{3} \mathrm{O}_{4}$ and $\mathrm{PANI}(\mathrm{EB}) / \mathrm{Fe}_{3} \mathrm{O}_{4}(\mathrm{OA})$ at $950{ }^{\circ} \mathrm{C}$, respectively, demonstrated high saturated magnetization of 138 and $197 \mathrm{emu} \mathrm{g}^{-1}$ compared to $82 \mathrm{emu} \mathrm{g}^{-1}$ of neat $\mathrm{Fe}_{3} \mathrm{O}_{4}$ and $30 \mathrm{emu} \mathrm{g}^{-1}$ of PANI(ES) $/ \mathrm{Fe}_{3} \mathrm{O}_{4}$, in accordance with Figure 9 a. The high magnetic moment of $\mathrm{FeNC}$ and $\mathrm{FeNC}(\mathrm{OA})$ derived from the formation of both $\alpha-\mathrm{Fe}$ and $\mathrm{Fe}_{3} \mathrm{C}$, as already confirmed in the section of X-ray diffraction patterns. However, the Ms of FeNC 
decayed by $23.2 \%$, from 138 to $106 \mathrm{emu} \mathrm{g}^{-1}$ in the air within two months, according to Figure 9a. For FeNC(OA), the decay was about $18.7 \%$, from 197 to $160 \mathrm{emu} \mathrm{g}^{-1}$, still less than that of FeNC (23.2\%) after a longer time (four months) at room temperature.
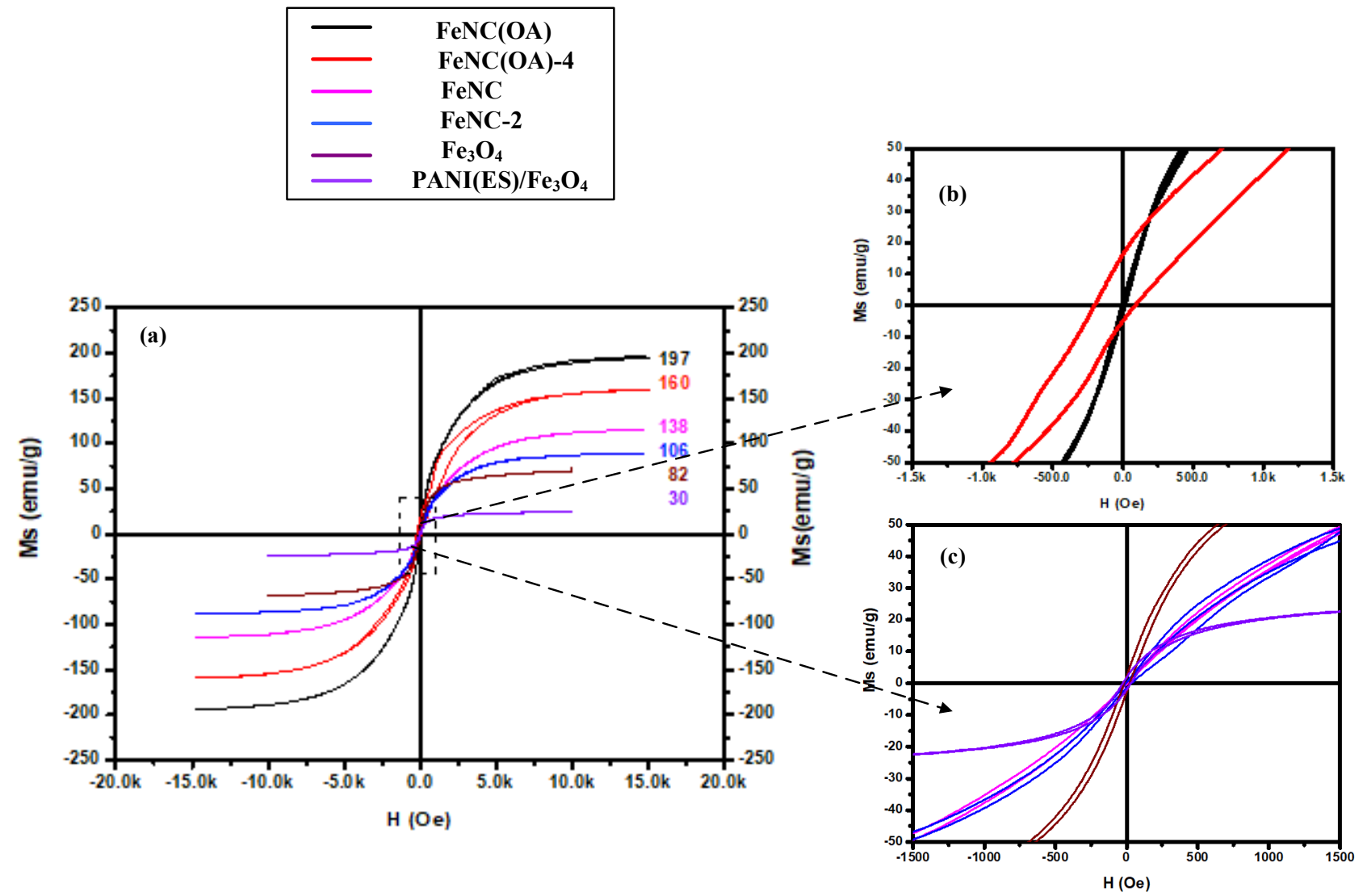

Figure 9. (a) SQUID curves for various iron compounds. (b,c) are enlarged insets of (a), respectively.

Regularly, the steep loss of magnetic moment of $\alpha$-Fe derived from the oxidation in air when it could not convert to other protective iron compounds, and low-magnetic-moment iron oxides became the main products. For either FeNC or FeNC(OA), a not significant increase of $\mathrm{Fe}_{3} \mathrm{O}_{4}$ was observed after two and four months in air, respectively (i.e., FeNC-2 and $\mathrm{FeNC}(\mathrm{OA})-4$ ) from their X-ray diffraction spectra. Therefore, the magnetic moment was lost mostly due to the transformation from high-magnetic-moment $\alpha$-Fe to $\mathrm{Fe}_{3} \mathrm{C}$, since not significant oxidation can occur in the air under the protection of the carbonized PANI. In Figure $7 \mathrm{~b}$ of the $\mathrm{X}$-ray pattern, an increasing peak of $\mathrm{Fe}_{3} \mathrm{C}$ and a decreasing peak of $\alpha$-Fe were observed only for FeNC-2, whereas such phenomenon was not observed for FeNC(OA)-2 which still had a high magnetic moment two months later. For FeNC-2, more newly formed $\mathrm{Fe}_{3} \mathrm{C}$ precipitated from the matrix (Figure 5g). Hard materials like $\mathrm{Fe}_{3} \mathrm{C}$ mixed with $\mathrm{FeNC}(\mathrm{OA})-2$ can effectively prevent further carbon diffusion into the inner $\alpha$-Fe matrix and stop the advanced conversion to $\mathrm{Fe}_{3} \mathrm{C}$. In other words, attaching a long alkyl chain to the surface of $\mathrm{Fe}_{3} \mathrm{O}_{4}$ nanoparticles via the inverse emulsion polymerization of PANI enhanced and stabilized the magnetization of the resultant $\mathrm{C}, \mathrm{N}$-doped iron compounds (FeNC(OA)). They successfully developed into dominant $\alpha$-Fe via calcination under the protection of the surrounding PANI molecules and maintained a high magnetic moment in air under the protection of some hard and stable $\mathrm{Fe}_{3} \mathrm{C}$.

All samples demonstrated perfect superparamagnetivity with slight hysteresis and not significant residual magnetivity, as shown in Figure 9a. Though some of the magnetization could be maintained after four months for $\mathrm{FeNC}(\mathrm{OA})-4$, hysteresis was enhanced according 
to Figure $9 \mathrm{~b}$ (upper inset diagram of Figure 9a); hysteresis was smaller for FeNC-2, as shown in Figure 9c (down inset diagram of Figure 9a).

\section{Conclusions}

OA tails were successfully attached to $\mathrm{Fe}_{3} \mathrm{O}_{4}\left(\mathrm{Fe}_{3} \mathrm{O}_{4}(\mathrm{OA})\right)$ nanoparticles by esterification, as revealed by IR spectra, which allowed them to be collected inside micelles during inverse emulsion polymerization. The strong blue shift of the UV-Vis-NIR spectrum of PANI(ES) demonstrated $\mathrm{Fe}_{3} \mathrm{O}_{4}(\mathrm{OA})$ was well mixed with PANI molecules formed inside micelles during polymerization. The larger size of the particles seen in the SEM micropictures indicated the strong magnetic moment of $\mathrm{FeNC}(\mathrm{OA})$. TEM micrographs indicated the presence of $\mathrm{Fe}_{3} \mathrm{C}$ after calcination, and the new-borne $\mathrm{Fe}_{3} \mathrm{C}$ either phase-separated or remained in the matrix of $\alpha$-Fe after exposure to air for two months. X-ray diffraction patterns of the iron compounds after calcination revealed the formation of $\mathrm{Fe}_{3} \mathrm{C}$ by sacrificing $\alpha$-Fe to $\mathrm{Fe}_{3} \mathrm{C}$ gradually in air, if it was not protected by the new-borne $\mathrm{Fe}_{3} \mathrm{C}$. The high, stable saturated magnetization $\left(197 \mathrm{emu} \mathrm{g}^{-1}\right)$ of FeNC(OA) resulted from affluent $\alpha$-Fe and demonstrated negligible decay in two months as a result of the protection of by new-borne $\mathrm{Fe}_{3} \mathrm{C}$.

Author Contributions: Conceptualization, T.-H.H. and Y.-Z.W.; methodology, C.-H.T.; formal analysis, L.-F.H.; investigation, L.-C.H.; writing-review and editing, K.-S.H.; supervision, Y.-Z.W.; funding acquisition, K.-S.H. All authors have read and agreed to the published version of the manuscript.

Funding: This research was funded by Ministry of Science and Technology in Taiwan, grant number, MOST 105-2622-E-151-012-CC3, MOST108-2221-E-992-037, MOST 109-2221-E-992-083, TAIFLEX Scientific co., LTD, grant number 104B5107.

Acknowledgments: Appreciation for the use of soft-matter TEM equipment belonging to the Instrument Center of National Cheng Kung Univ. (NCKU), Ministry of Science and Technology in Taiwan, ROC.

Conflicts of Interest: The funders had no role in the design of the study; in the collection, analyses, or interpretation of data; in the writing of the manuscript, or in the decision to publish the results.

\section{References}

1. Ansari, F.; Sobhani, A.; Salavati-Niasari, M. Green synthesis of magnetic chitosan nanocomposites by a new sol-gel autocombustion method. J. Magn. Mater. 2016, 410, 27-33. [CrossRef]

2. Zhang, B.; Du, Y.; Zhang, P.; Zhao, H.; Kang, L.; Han, X.; Xu, P. Microwave absorption enhancement of $\mathrm{Fe}_{3} \mathrm{O}_{4} /$ polyaniline core/shell hybrid microspheres with controlled shell thickness. J. Appl. Polym. Sci. 2013, 130, 1909-1916. [CrossRef]

3. Yamanaka, K.; Onuma, Y.; Yamashita, S.; Masubuchi, Y.; Takeda, T.; Kikkawa, S. Humidity effects in $\mathrm{Fe}_{16} \mathrm{~N}_{2}$ fine powder preparation by low-temperature nitridation. J. Solid State Chem. 2010, 183, 2236-2241. [CrossRef]

4. Li, X.; Xi, S.; Sun, L.; Dou, S.; Huang, Z.; Su, T.; Wang, X. Isolated FeN 4 Sites for Efficient Electrocatalytic $\mathrm{CO}_{2}$ Reduction. Adv. Sci. 2020, 7, 2001545. [CrossRef] [PubMed]

5. Jian, Y.; Mehedi, M.A.; Fu, E.; Wang, Y.; Allard, L.F.; Wang, J.-P. Synthesis of $\mathrm{Fe}_{16} \mathrm{~N}_{2}$ compound Free-Standing Foils with $20 \mathrm{MGOe}$ Magnetic Energy Product by Nitrogen Ion-Implantation. Sci. Rep. 2016, 6, 25436. [CrossRef] [PubMed]

6. Masubuchi, Y.; Motohashi, S.Y.; Kikkawa, T.S.; Niederberger, M. Magnetite/maghemite mixture prepared in benzyl alcohol for the preparation of $\alpha^{\prime \prime}-\mathrm{Fe}_{16} \mathrm{~N}_{2}$ with $\alpha$-Fe. J. Eur. Ceram. Soc. 2011, 31, 2471-2474. [CrossRef]

7. Liang, P.X.; Lu, X.; Wang, S.; Li, Y.; Wang, L.; Guo, Y. Preparation of magnetic carbonized polyaniline nanotube and its adsorption behaviors of xanthene colorants in beverage and fish samples. J. Chromatogr. A 2019, 1605, 460369.

8. Ghadimi, L.S.; Arsalani, N.; Tabrizi, A.G.; Mohammadi, A.; Ahadzadeh, I. Novel nanocomposite of $\mathrm{MnFe}_{2} \mathrm{O}_{4}$ and nitrogen-doped carbon from polyaniline carbonization as electrode material for symmetric ultra-stable supercapacitor. Electrochim. Acta 2018, 282, 116-127. [CrossRef]

9. Chen, X.; Zhang, Y.; Tao, L.; Nie, Q.; Meng, F.; Cui, S.L.; Huang, R. Ferromagnetic carbonized polyaniline/nanodiamond hybrids for ultrabroad-band electromagnetic absorption. Carbon 2020, 164, 224-234. [CrossRef]

10. Sim, B.; Chae, H.S.; Choi, H.J. Fabrication of polyaniline coated iron oxide hybrid particles and their dual stimuli-response under electric and magnetic fields. eXPRESS Polym. Lett. 2015, 9, 736-743. [CrossRef]

11. Wang, Y.-Z.; Tsai, M.-J.; Hsieh, T.-H.; Tseng, P.-H.; Lu, C.-Y.; Ho, K.-S. Studies on one-dimensional polyanilines prepared with n-dodecylbenzenesulfonic and camphorsulfonic acids. Polym. Int. 2015, 64, 1568-1577. [CrossRef]

12. Cheng, Y.-W.; Chao, L.; Wang, Y.-M.; Ho, K.-S.; Shen, S.-Y.; Hsieh, T.-H.; Wang, Y.-Z. Branched and phenazinized polyaniline nanorod prepared in the presence of meta-phenylenediamine. Synth. Met. 2013, 168, 48-57. [CrossRef] 
13. Wu, Y.-J.; Ho, K.-S.; Cheng, Y.-W.; Chao, L.; Wang, Y.-Z.; Hsieh, T.-H.; Ho, T.-H.; Han, Y.-K. Studies on the synthesis of low molecular weight, one-dimensional polyanilines prepared by fast emulsion polymerization using (n-dodecylbenzenesulfonic acid) $/ \mathrm{HCl}$ emulsifiers. Polym. Int. 2013, 62, 581-590. [CrossRef]

14. Chao, L.; Ho, K.-S.; Shen, S.-Y.; Pu, H.-Y.; Hsieh, T.-H.; Kuo, C.-W.; Tseng, B.-H. Short polyaniline nanorod prepared in the presence of para-phenylenediamine. J. Appl. Polym. Sci. 2013, 127, 1853-1862. [CrossRef]

15. Ho, K.-S.; Han, Y.-K.; Tuan, Y.-T.; Huang, Y.-J.; Wang, Y.-Z.; Ho, T.-H.; Hsieh, T.-H.; Lin, J.-J.; Lin, S.-C. Formation and Degradation Mechanism of a Novel Nanofibrous polyaniline. Synth. Met. 2009, 159, 1202-1209. [CrossRef]

16. Basavaiah, K.; Kumar, Y.P.; Prasada Rao, A.V. A facile one-pot synthesis of polyaniline/magnetite nanocomposites by micellesassisted method. Appl. Nanosci. 2013, 3, 409-415. [CrossRef]

17. Gabunada, J.C.; Vinothkannan, M.; Kim, D.H.; Kim, A.R.; Yoo, D.J. Magnetite Nanorods Stabilized by Polyaniline/Reduced Graphene Oxide as a Sensing Platform for Selective and Sensitive Non-enzymatic Hydrogen Peroxide Detection. Electroanalysis 2019, 31, 1507-1516. [CrossRef]

18. Intan Subadra, S.T.U.; Sutiami, R.; Taufiq, A.; Sunaryono, M.; Hidayat, A.; Mufti, N.; Hidayat, N.; Susanto, H.; Ari Adi, W. Preparation and Characterization of Magnetite Nanoparticles Combined with Polyaniline and Activated Carbon. IOP Conf. Ser. Earth Environ. Sci. 2019, 276, 012041. [CrossRef]

19. Xu, F.; Ma, L.; Gan, Q.M.; Tang, J. Microwave absorbing properties and structural design of microwave absorbers based on polyaniline and polyaniline/magnetite nanocomposite. J. Magn. Magn. Mater. 2015, 374, 311-316. [CrossRef]

20. Batool, R.; Akhtar, M.A.; Hayat, A.; Han, D.; Niu, L.; Ahmad, M.A.; Nawaz, M.H. A nanocomposite prepared from magnetite nanoparticles, polyaniline and carboxy-modified graphene oxide for non-enzymatic sensing of glucose. Microchim. Acta 2019, 186, 267. [CrossRef]

21. Zanotto, C.; Ratuchne, F.; de Castro, E.G.; Marques, P.T. Structural Characterization of Magnetite and its Influence on the Formation of Composites with Polyaniline. Orbital Electron. J. Chem. 2019, 11, 427-432. [CrossRef]

22. Farias-Mancilla, R.; Elizalde-Galindov, J.T.; Vigueras-Santiago, E.; Hernández-Escobar, C.A.; Vega-Rios, A.E.; Zaragoza-Contreras, A. Synthesis and Characterization of Polyaniline/Magnetite Nanocomposite. Int. J. Theor. Appl. Nanotechnol. 2016, 4, 1-8. [CrossRef]

23. Kim, J.H.; Fang, F.F.; Choi, H.J.; Seo, Y. Magnetic composites of conducting polyaniline/nano-sized magnetite and their magnetorheology. Mater. Lett. 2008, 62, 2897-2899. [CrossRef]

24. Takai, Z.-I.; Mustafa, M.-K.; Asman, S.; Sekak, K.-A. Preparation and Characterization of Magnetite $\left(\mathrm{Fe}_{3} \mathrm{O}_{4}\right)$ nanoparticles By Sol-Gel Method. Int. J. Nanoelectron. Mater. 2019, 12, 37-46.

25. Huang, W.-Y.; Chang, M.-Y.; Wang, Y.-Z.; Huang, Y.-C.; Ho, K.-S.; Hsieh, T.-H.; Kuo, Y.-C. Polyaniline Based Pt-Electrocatalyst for a Proton Exchanged Membrane Fuel Cell. Polymers 2020, 12, 617. [CrossRef]

26. Wang, Y.Z.; Huang, W.Y.; Hsieh, T.H.; Jheng, L.C.; Ho, K.S.; Huang, S.W.; Chao, L. FeNxC Based Catalysts Prepared by the Calcination of Iron-Ethylenediamine@Polyaniline as the Cathode-Catalyst of Proton Exchange Membrane Fuel Cell. Polymers 2019, 11, 1368. [CrossRef]

27. Tseng, P.-H.; Wang, Y.-Z.; Hsieh, T.-H.; Ho, K.-S.; Huang, P.-C.; Lo, W.-T. Facile way to prepare one dimensional Ag@oligoaniline wires. J. Taiwan Inst. Chem. Eng. 2017, 81, 445-454. [CrossRef]

28. Hsieh, B.-Z.; Chuang, H.-Y.; Chao, L.; Li, Y.-J.; Huang, Y.-J.; Tseng, P.-H.; Hsieh, T.-H.; Ho, K.-S. Formation mechanism of a nanotubular polyanilines prepared by an emulsion polymerization without organic solvent. Polymer 2008, 49, 4218-4225. [CrossRef]

29. Shen, S.-Y.; Wu, Y.-J.; Ho, K.-S.; Hsieh, T.-H.; Ho, T.-H.; Wang, Y.-Z.; Tseng, P.-H.; Hsu, Y.-C. Branched and curved nanotubular polyaniline synthesized by emulsion polymerization in presence of zinc salts of n-dodecylbenzenesulfonic acid. Polymer 2011, 52, 2609-2617. [CrossRef]

30. Sheng, Z.-H.; Shao, L.; Chen, J.-J.; Bao, W.-J.; Wang, F.-B.; Xia, X.-H. Catalyst-Free Synthesis of Nitrogen-Doped Graphene via Thermal Annealing Graphite Oxide with Melamine and Its Excellent Electrocatalysis. ACS Nano. 2011, 5, 4350-4358. [CrossRef]

31. Jaouen, F.; Proietti, E.; Lefèvre, M.; Chenitz, R.; Dodelet, J.-P.; Wu, G.; Chung, H.T.; Johnston, C.M.; Zelenay, P. Recent advances in non-precious metal catalysis for oxygen-reduction reaction in polymer electrolyte fuel cells. Energy Environ. Sci. 2011, 4, 114-130. [CrossRef]

32. Chen, Z.; Higgins, D.; Yu, A.; Zhang, L.; Zhang, J. A review on non-precious metal electrocatalysts for PEM fuel cells. Energy Environ. Sci. 2011, 4, 3167-3192. [CrossRef] 